\title{
Geochemistry and Geochronology of Early Paleozoic Intrusive Rocks in the Terra Nova Bay Area, Northern Victoria Land, Antarctica
}

\author{
Daeyeong Kim ${ }^{1} \mathbb{D}$, Sang-Bong Yi ${ }^{1, * \mathbb{D}}$, Hyeoncheol Kim ${ }^{2}$, Taehwan Kim ${ }^{1}$, Taehoon Kim ${ }^{3}$ and Jong Ik Lee ${ }^{1}$ \\ 1 Division of Earth Sciences, Korea Polar Research Institute, Incheon 21990, Korea; dkim@kopri.re.kr (D.K.); \\ taehwan.kim@kopri.re.kr (T.K.); jilee@kopri.re.kr (J.I.L.) \\ 2 Geology Division, Korea Institute of Geoscience and Mineral Resources, Daejeon 34132, Korea; \\ hckim@kigam.re.kr \\ 3 Geoscience Platform Division, Korea Institute of Geoscience and Mineral Resources, Daejeon 34132, Korea; \\ tkim@kigam.re.kr \\ * Correspondence: handjive@kopri.re.kr
}

check for updates

Citation: Kim, D.; Yi, S.-B.; Kim, H.; Kim, T.; Kim, T.; Lee, J.I.

Geochemistry and Geochronology of Early Paleozoic Intrusive Rocks in the Terra Nova Bay Area, Northern Victoria Land, Antarctica. Minerals 2021, 11, 787. https://doi.org/ $10.3390 / \min 11070787$

Academic Editors:

Hans-Jürgen Förster and Sven Fuchs

Received: 24 June 2021

Accepted: 16 July 2021

Published: 20 July 2021

Publisher's Note: MDPI stays neutral with regard to jurisdictional claims in published maps and institutional affiliations.

Copyright: (c) 2021 by the authors. Licensee MDPI, Basel, Switzerland. This article is an open access article distributed under the terms and conditions of the Creative Commons Attribution (CC BY) license (https:/ / creativecommons.org/licenses/by/ $4.0 /)$.
Abstract: The Terra Nova Intrusive Complex (TNIC) in northern Victoria Land, Antarctica, results from widespread magmatism during the Early Paleozoic Ross Orogeny. According to field relationships, geochemistry, and geochronology data, the northern part of the TNIC comprises the Browning Intrusive Unit (BIU), which is associated with an arc crustal melting including migmatization of the Wilson Metamorphic Complex, and the later Campbell Intrusive Unit (CIU), which is attributed to the mantle and crustal melting processes. Zircon U-Pb ages suggest Late Neoproterozoic to Early Cambrian protolith with Late Cambrian metamorphism (502 $\pm 15 \mathrm{Ma}$ ) in the WMC, Late Cambrian formation ( $500 \mathrm{Ma}$ ) of the BIU, and Early Ordovician formation ( 480-470 Ma) of the CIU. Sr-Nd isotopic characteristics of the BIU indicate predominant crustal component $\left(\varepsilon \mathrm{Nd}_{(\mathrm{t})}=-8.7\right.$ to -8.9$)$, whereas those of the CIU reflect both mantle $\left(\varepsilon \mathrm{Nd}_{(\mathrm{t})}=1.8\right.$ to 1.6) and crustal $\left(\varepsilon \mathrm{Nd}_{(\mathrm{t})}=-4.0\right.$ to -7.5$)$ compositions. These results suggest that the northern TNIC magmatism occurring at $\sim 500-470 \mathrm{Ma}$ originated from partial melting of the mantle-mafic crust components and mixing with felsic crust components. By integrating the results with previous studies, the TNIC is considered to be formed by a combination of the mantle and mafic crust melting, crustal assimilation, felsic crust melting, and magma mixing during the Ross Orogeny.

Keywords: Ross Orogeny; Terra Nova Intrusive Complex (TNIC); northern Victoria Land (NVL); zircon $\mathrm{U}-\mathrm{Pb}$ age; $\mathrm{Sr}-\mathrm{Nd}$ isotopes

\section{Introduction}

The present tectonic setting in Antarctica is associated with diverse orogenic events which occurred during the Archean-Phanerozoic [1-7]. The Early Paleozoic Ross-Delamerian Orogeny was a prominent event along the Paleo-Pacific margin of the Gondwana supercontinent, where continental accretion and suturing have been documented (e.g., [5-11]). Northern Victoria Land (NVL), which is located at the northern end of the Transantarctic Mountains (TAM), was formed mainly from this event.

Magma intrusion and emplacement in continental margin environments are affected by many factors, such as the source material and its interactions during a multi-stage, multicomponent, and multi-process event. The Terra Nova Intrusive Complex (TNIC: [12,13]) in NVL contains a number of magma batches emplaced in a continental arc during the early stage of the Paleozoic Ross Orogeny. Multiple emplacements of magma pulses in the TNIC are revealed by several petrology and geochemistry data from mafic to felsic intrusive rocks (e.g., [14]). However, in previous studies, the northern part of the TNIC has been neglected probably because of the limited outcrops, inaccessibility, and harsh weather conditions. 
In the present study, we report the data for intrusive bodies of varying mafic to felsic compositions found in the poorly studied northern part of the TNIC, as part of the Korean Antarctic Research Program that was based in the Jang Bogo Station during the 2016-2018 austral summer seasons [15]. We discuss the origin and genesis of the Terra Nova continental crust using the field, geochronological, and petrological relationships between intrusive rocks in the TNIC.

\section{Geological Setting}

Basement rocks in the TAM, which comprises NVL, southern Victoria Land, central TAM, southern TAM, and the Pensacola Mountains, were affected by the Ross Orogeny (Figure 2a). The orogeny is attributed to convergence between the Paleo-Pacific oceanic lithosphere and the continental margin of Gondwana during the Cambrian to Ordovician [16-18]. NVL contains three accretionary terranes, including low-grade (meta)sedimentary rocks of the Robertson Bay Terrane (northeast), variably metamorphosed volcano-sedimentary rocks of the Bowers Terrane, and high-grade metasedimentary rocks (Wilson Metamorphic Complex; WMC) and the Granite Harbor Intrusives (GHI) of the Wilson Terrane (southwest) [14,19-22].

The TNIC, which is a part of the GHI, is defined by outcrops located in the coastal area between the Campbell and David glaciers (Figure 2b). The central-south TNIC can be subdivided into the Terra Nova Orthogneisses (gray in Figure 2c), Confusion Unit, Abbott Unit, Inexpressible Syenites, and Vegetation Unit, based on field, geochemistry, and geochronology data [13]. The Terra Nova Orthogneisses are exposed near the WMC (Gerlache Inlet; included in the WMC in Figure 2c) and in the mid-western part of the Inexpressible Island (gray in the Inexpressible Island in Figure 2c). The Confusion Unit intrusive rocks, which are characterized by multiple deformation features, intruded the Terra Nova orthogneisses and were in turn crosscut by rocks of the Vegetation Unit. The lack of evidence for strain in the Inexpressible Island Syenites suggests that these were emplaced in a shallow and tensional regime [13]. Mafic and felsic rocks from the Vegetation Unit ( 475 Ma) are characterized by slight and pronounced enrichment in isotopes and incompatible elements than those of the Abbott Unit ( 495 Ma) [12,13]. In addition to emplacement styles and depths ranging from forcible at $\sim 0.6-0.4 \mathrm{GPa}$ for the Abbot Unit to passive at $\sim 0.2 \mathrm{GPa}$ for the Vegetation Unit, these characteristics reflect a major change in the tectonic setting from a compression toward an intracontinental extension [12,23-25].

The study area (northern TNIC), which was described as the Wilson Terrane Metamorphic Complex in previous studies (e.g., $[12,13,19])$, comprises the WMC, Browning Intrusive Unit (BIU), and Campbell Intrusive Unit (CIU) from south to north (Figure 2c). The BIU and CIU are distinguished mainly based on their field relationships and ages. The WMC is located north of the Abbott Unit, where the Jang Bogo Station was built. It is considered the oldest lithologic unit and contains migmatitic gneisses and biotite schist with minor amphibolite and amphibole schist $[26,27]$. The BIU comprises foliated porphyritic granite and leucogranite, while the CIU contains massive gabbroic and dioritic rocks, leucogranite, and biotite granite. Dating results for each unit are examined in detail in Section 3. 


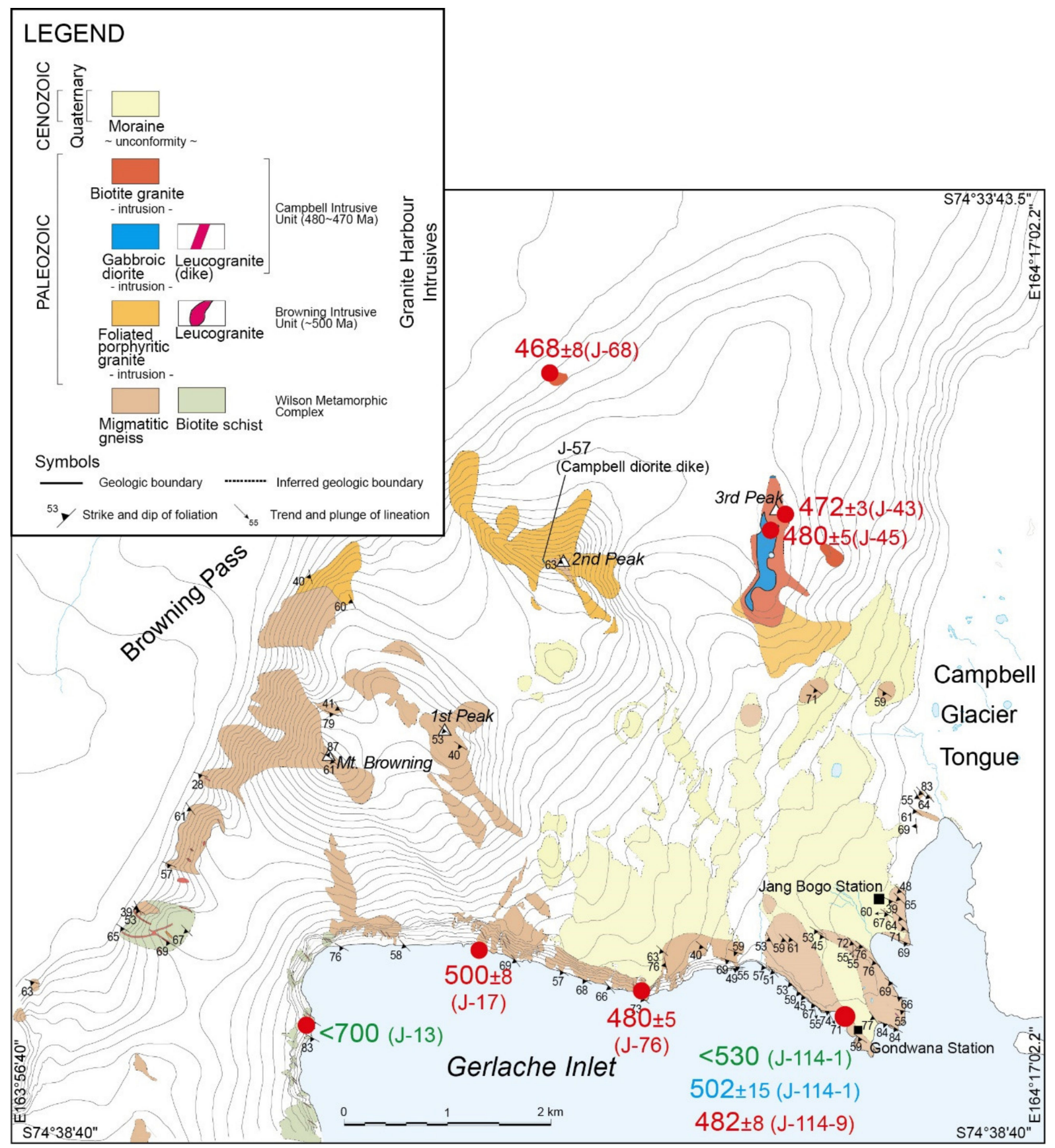

Figure 1. Geologic map of the study area (modified from [15]) showing zircon U-Pb ages (in Ma) obtained in the present study and the associated sample numbers. Values in green, blue, and red denote deposition, metamorphic, and igneous ages, respectively. 


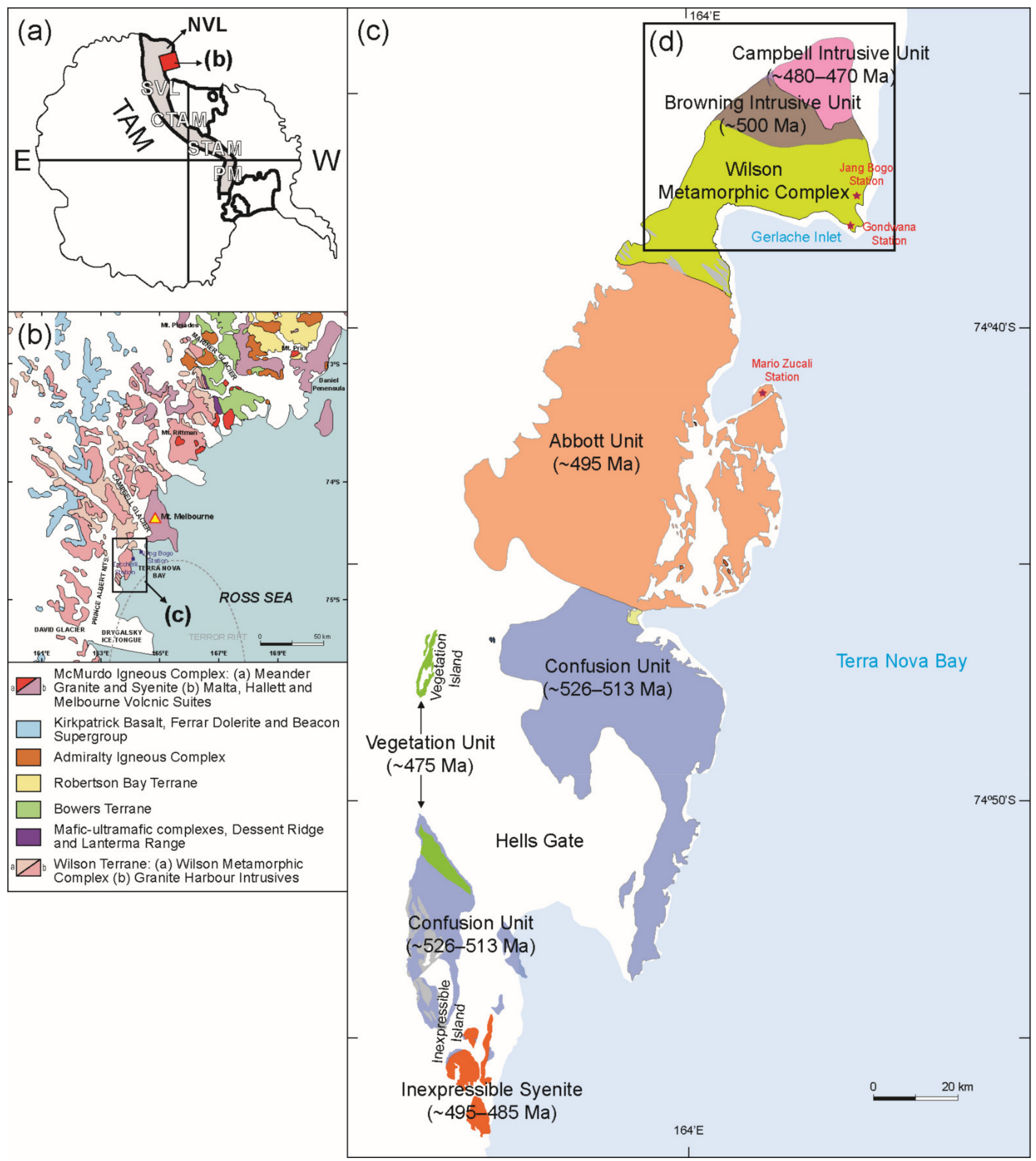

Figure 2. Maps (modified from [13,28]) showing (a) the location of northern Victoria Land (NVL) in Antarctica, (b) geologic of NVL including the distribution of rocks in the Granite Harbour Intrusives (GHI), (c) simplified geology of the Terra Nova Intrusive Complex (TNIC) and the Wilson Metamorphic Complex (WMC), and (d) the study area. A map with details for (d) is provided in Figure 1. TAM: Transantarctic Mountains; SVL: southern VL; CTAM: central TAM; STAM: southern TAM; PM: Pensacola Mountains. 


\section{Field Occurrences and Relationships}

\subsection{Wilson Metamorphic Complex (Precambrian-Early Cambrian Protoliths)}

The study area, which is in the northern part of the TNIC, comprises the WMC and the GHI (Figures 1 and 2). The WMC in the study area contains mostly migmatitic gneisses and (garnet)-biotite schists (hereafter biotite schists), with minor amphibolite and amphibole schist, as well as biotite-hornblende gneisses, which have experienced complex metamorphic events (Figure 3a,b and Figure 4a,b) [27]. Although leucogranite dikes are rare in the geologic map (Figure 1), small scales of outcrops are abundant in the whole area.
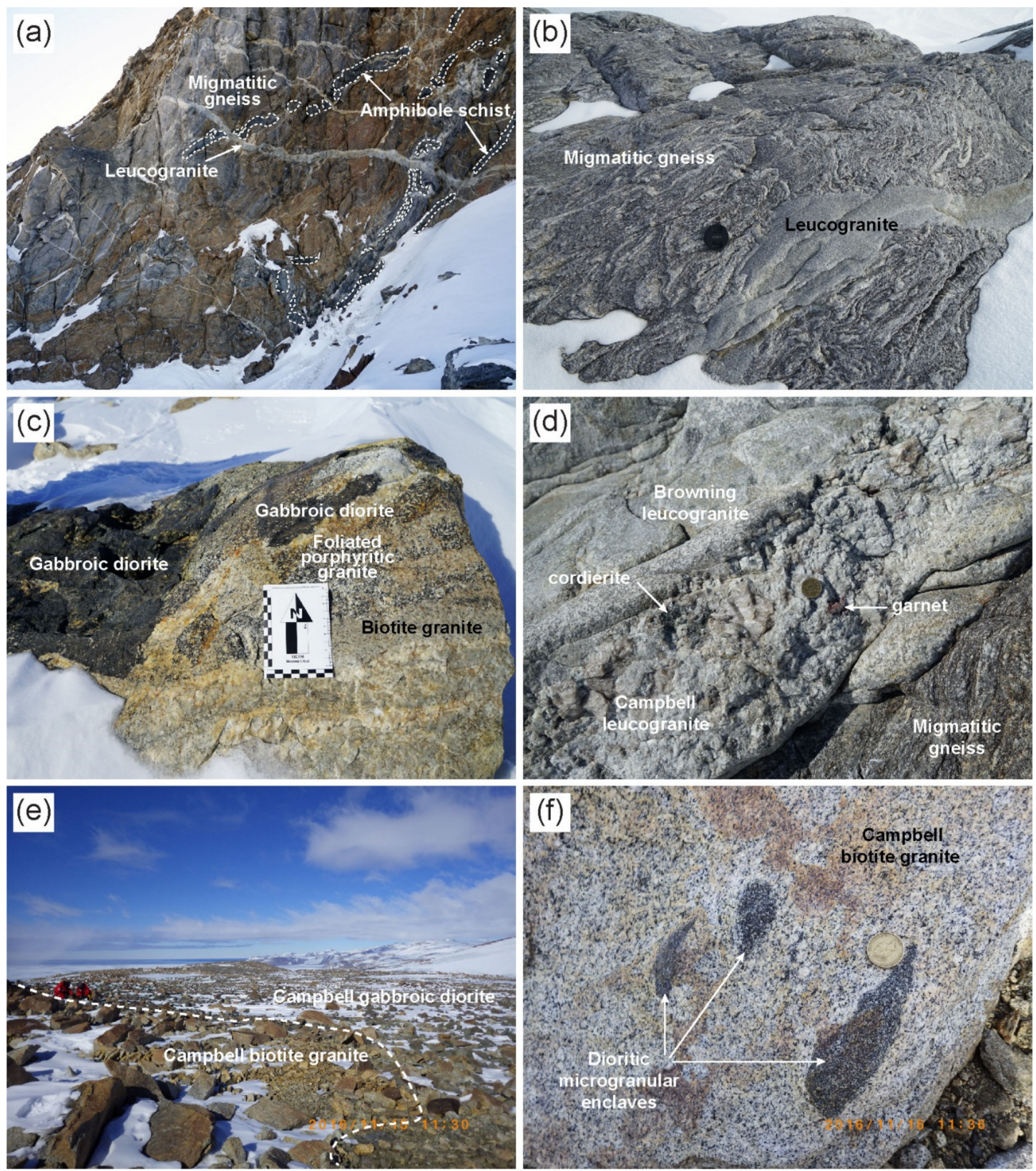

Figure 3. Outcrop photographs showing (a) migmatitic gneisses and amphibole schists intruded by leucogranites at a high angle to the foliation, (b) migmatitic gneisses intruded by leucogranites, (c) the Campbell gabbroic diorites and biotite granites crosscutting the Browning foliated porphyritic granites, and (d) two leucogranites types (Browning two-mica leucogranite and Campbell K-feldspar megacryst leucogranite) which intruded migmatitic gneisses. (e) The inferred boundary between biotite granites and gabbroic diorites in the CIU near the 3rd Peak. The biotite granites are recognized through the presence of large and light-colored blocks in the field. (f) The Campbell biotite granites hosting dioritic microgranular enclaves. 

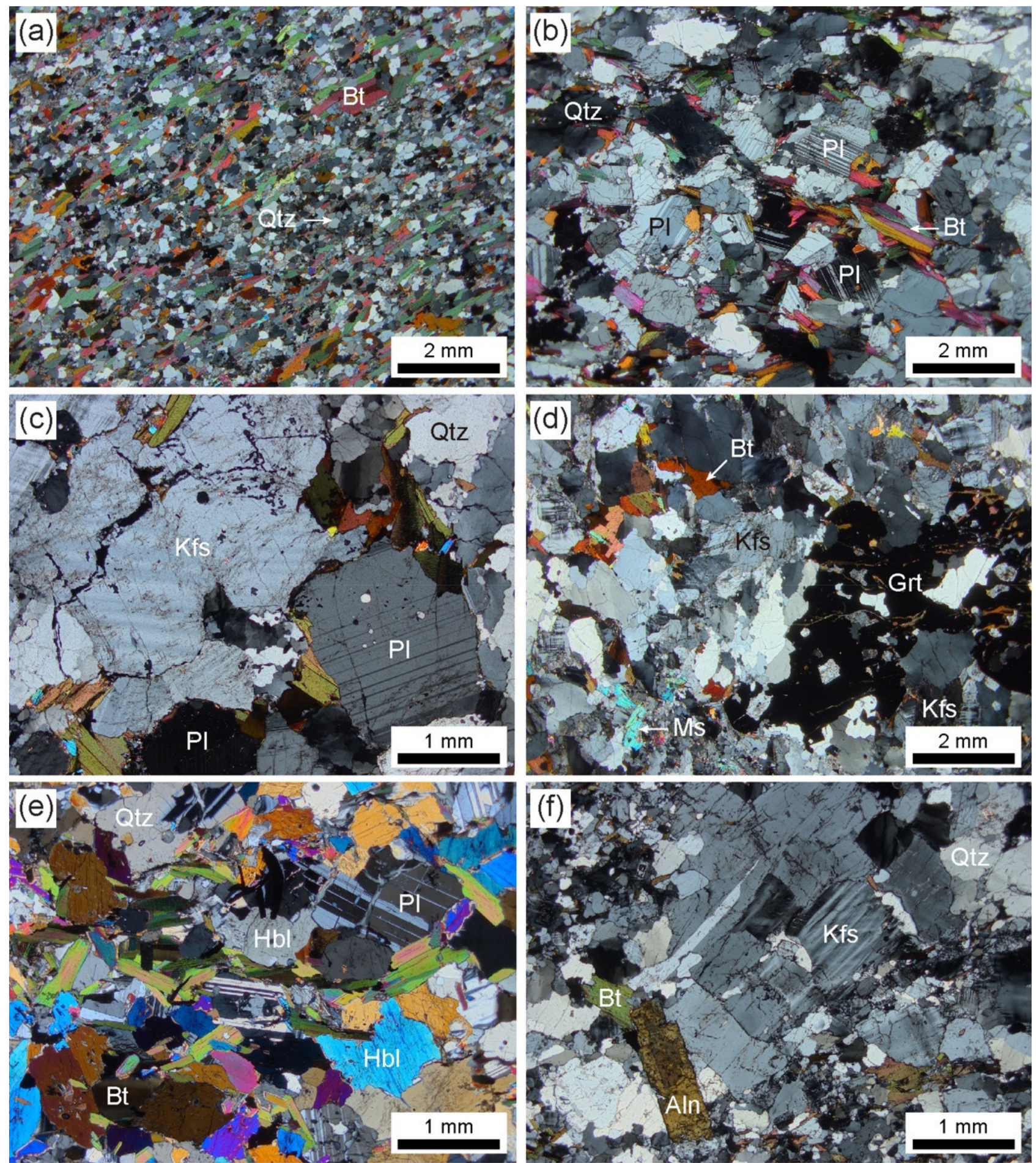

Figure 4. Photomicrographs of the studied rocks displaying (a) fine-grained flakes of biotite aligned subparallel to the foliation in biotite schist of the Wilson Metamorphic Complex, (b) quartz grains exhibiting sutured boundaries and undulatory extinctions in a migmatitic gneiss of the Wilson Metamorphic Complex, (c) the Browning foliated porphyritic granite showing fractures in plagioclase and K-feldspar, (d) poikilitic garnet in the Browning leucocratic granite, (e) the Campbell gabbroic diorite containing hornblende, plagioclase, and biotite, characterized by an equigranular texture, and (f) the Campbell biotite granite without a foliated texture. Photos were taken under a cross-polarized light. Bt: biotite; Qtz: quartz; Pl: Plagioclase; Kfs: K-feldspar; Grt: garnet; Ms: muscovite; Hbl: hornblende; Aln: allanite. 
Biotite schists exposed along the western cliff of the Gerlache Inlet and to the southeast of the Browning Pass are relevant with schists in the Wilson Terrane [29] and the amphibolite facies metasediments in the WMC $[13,30]$. These biotite schists are characterized by extensive leucogranite intrusions parallel or at high angles to foliations (Figure 3a). Major foliation planes created by biotite and muscovite alignment display NW strikes and SW dips (Figures 1 and 4a). Principal mineral assemblages in the biotite schists are garnet, biotite, plagioclase, and quartz, with minor muscovite. The major foliation envelops garnet porphyroblasts, suggesting pre- to synkinematic formation. These biotite schists display smaller grains and contain lower metamorphic grade mineral assemblages compared to the migmatitic gneisses.

Migmatitic gneisses exposed in the Mt. Browning area with the 1st Peak near the Jang Bogo and Gondwana stations were intruded by the polyphase leucogranites (Figure 3a,b,d). These leucogranites are either concordant or discordant to the major foliation, although some veinlets extend into granitic neosomes of the migmatitic gneisses. The mineral assemblage of the migmatitic gneisses mainly comprises sillimanite, cordierite, garnet, biotite, muscovite, plagioclase, K-feldspar, quartz, and rare spinel (Figure 4b). Fibrolitic sillimanite is common and coexists with biotite, cordierite, plagioclase, and K-feldspar. Cordierite exhibits signs of replacement by muscovite and chlorite (pinitization) during retrogression, while the rare spinel occurs as an anhedral relict phase in the cordierite.

\subsection{Browning Intrusive Unit (Late Cambrian)}

Intrusive rocks in the study area belong to the BIU-CIU (Figures 1 and 2), and these units are characterized by distinct foliations. The BIU comprises two separate plutons: foliated porphyritic granites and two-mica leucogranites, which intruded the WMC. This unit was in turn intruded by gabbros, diorites, and biotite granites of the Early Ordovician CIU (Figure 3c), which implies the BIU was formed during the Late Cambrian.

The foliated porphyritic granites, which are characterized by weak to moderate foliations and medium- to coarse-grained textures as well as feldspar phenocrysts (plagioclase and K-feldspar), locally display a heterogeneous distribution of minerals. Foliated porphyritic granites which were previously assigned to the WMC [30,31] are distinguished from the surrounding metamorphic rocks by the lack of metamorphic differentiation which produces leucocratic and melanocratic layers. Although this porphyritic granite commonly shows foliations that distinguish it from the biotite granite of the CIU (Figure 3e), it also locally exhibits massive or weakly foliated structures. Occasionally, foliated mafic xenoliths are also seen in this granite, and these are often biotite-enriched remnants of the host schists or gneisses. Major minerals in these foliated porphyritic granites are biotite, plagioclase, K-feldspar, and quartz (Figure 4c). Plagioclase and K-feldspar phenocrysts show lengths varying between 10-30 mm, whereas biotite and other minerals are unevenly distributed at the outcrop scale. Quartz grains in the granites show undulatory extinction and sutured boundaries, with some recrystallization into subgrains along margins. In addition, fractures are common in the plagioclase and K-feldspars (Figure $4 \mathrm{c}$ ).

Two-mica leucogranites intruded biotite schists and migmatitic gneisses of the WMC along foliations as dikes or veinlets, thereby frequently forming lens-shaped boudins (Figure 3d). Foliations in the two-mica leucogranites depend on the alignment of biotite and are consistent with those of the host metamorphic rocks. Therefore, axial planes of the folded leucogranite and the major foliation plane of the metamorphic rocks yield similar strikes and dips. The two-mica leucogranite comprises mostly quartz and feldspars, with minor biotite and muscovite. This leucogranite also locally contains cordierite and garnet, and these are often aligned parallel to foliations. In addition, narrow veinlets of the leucogranite occasionally extend into felsic neosomes of the migmatites. Although foliations in the leucogranites are associated with magmatic emplacement, some foliations were formed after solidification. Muscovite is commonly present in the pressure shadow zones of garnets but it is also occasionally wrapped in fibrolitic sillimanite. In addition, the 
foliated leucogranites exhibit planar textures containing lath-like K-feldspar, plagioclase, and elongated quartz. Most of the minerals are characterized by fractures, except for micas.

\subsection{Campbell Intrusive Unit (Early Ordovician)}

The CIU contains Early Ordovician igneous rocks that intruded both the WMC and BIU (Figure 1). This unit comprises three separate plutons: gabbroic and dioritic rocks, K-feldspar megacryst leucogranites, and biotite granites, which exhibit massive or weakly foliated structures.

The gabbroic and dioritic rocks (hereafter gabbroic diorites) are dark greenish gray, massive, and fine-to medium-grained rocks including comagmatic gabbro, monzodiorite, monzonite, and diorite, whose rock names are based on whole-rock chemical composition ([32], see Section 5). Although the gabbroic diorite pluton is enclosed by the biotite granite pluton (Figure 3e), the contact relationship between the two plutons is unclear because of the lack of continuous outcrops. Nevertheless, rock types in the two plutons are roughly discriminated in outcrops based on color (Figure 3e). These gabbroic diorites primarily contain hornblende, biotite, plagioclase, and quartz, with minor titanite (Figure 4e).

The K-feldspar megacryst leucogranites occur as dikes and veinlets, which commonly crosscut foliations in schists and gneisses of the WMC. Although some veinlets are folded, no evidence of penetrative deformation was observed in outcrops. Biotite selvages are common between the leucogranites and migmatitic gneisses. These Campbell leucogranites contain mainly K-feldspar, plagioclase, and quartz, with minor cordierite, garnet, and biotite (Figure 3d). Temporally, the relationship between the K-feldspar megacryst (CIU) and two-mica (BIU) leucogranites was unresolved by field observations. In some outcrops, however, K-feldspar megacryst leucogranites (CIU) intruded two-mica leucogranites (BIU) (Figure 3d).

Biotite granites enclosing the gabbroic diorite pluton are massive to weakly foliated and medium-to coarse-grained. These granites also occur as dikes that intruded foliated porphyritic granites (Figure 3c) and biotite schists exposed along the Browning Pass (Figure 1). The biotite granites contain abundant gabbroic diorite and migmatitic gneiss xenoliths as well as dioritic microgranular enclaves (Figure 3f). The biotite granites consist of biotite, plagioclase, K-feldspar (microcline), and quartz as the principal minerals, and minor allanite and titanite (Figure 4f).

\section{Analytical Methods}

Forty-five samples were analyzed for major and trace elements. Major element compositions were determined using a Shimadzu MXF-2400 X-ray fluorescence (XRF) spectrometer in the Korea Institute of Geoscience and Mineral Resources (KIGAM). Trace elements in the samples were analyzed using XRF glass bead, with laser ablation inductively coupled plasma mass spectrometry (LA-ICP-MS) (Nexion 350, Perkin Elmer attached with NWR 193UC, ESI) in KIGAM. Standard reference glass NIST 612 was used as an external standard, and trace element concentrations were calculated with ${ }^{44} \mathrm{Ca}$ as an internal standard.

Zircon grains were separated from two metamorphic and six intrusive rock samples using standard procedures, including density and magnetic separations, followed by handpicking under a binocular microscope. Internal textures of individual zircon grains were examined in the back-scattered electron and cathodoluminescence (CL) modes using a scanning electron microscope (JEOL JSM-6610LV) in the Ochang Center of the Korea Basic Science Institute (KBSI). Zircon cores were analyzed for schist and gneiss samples, while magmatic rims displaying oscillatory zoning in CL were used for granitoid samples. In situ U-Pb zircon ages were obtained using a sensitive high-resolution ion microprobe (SHRIMP) IIe housed in the KBSI (Ochang Center) and an LA-ICP-MS installed in the KIGAM. Zircon standards including SL13 (U = 238 ppm), FC1 (1099 Ma; [33]), and 91500 $\left({ }^{206} \mathrm{~Pb} /{ }^{238} \mathrm{U}\right.$ age $=1065.4 \mathrm{Ma}$; [34] $)$ were used to calibrate the $\mathrm{U}$ concentration and $\mathrm{Pb} / \mathrm{U}$ ratios. The SHRIMP analysis was performed according to procedures described in previous studies (e.g., [35]), and data were reduced using the Squid Exel macro [36]. For U-Pb age 
determination with LA-ICP-MS, the laser repetition rate, energy density, and spot diameter were set to $10 \mathrm{~Hz}, 4 \mathrm{~J} / \mathrm{cm}$, and $35 \mu \mathrm{m}$, respectively. Finally, both SHRIMP and LA-ICP-MS data were plotted using the Isoplot/Ex (v.3.6) [37]. We utilized reduced data that passed the statistical $t$-test to report at the $95 \%$ confidence level, and ${ }^{204} \mathrm{~Pb}$ corrected isotope ratios were employed for all plots and weighted mean age calculations.

Ten rock samples were also analyzed for $\mathrm{Rb}-\mathrm{Sr}$ and $\mathrm{Sm}-\mathrm{Nd}$ isotopic compositions using a Thermo-Fischer Triton plus, which was operated in the static mode in KIGAM. Samples were dissolved in an acid mixture (ultra-pure $\mathrm{HF}: \mathrm{HNO}_{3}=2: 1$ ) in Savillex Teflon vessels, which were sealed after adding ${ }^{87} \mathrm{Rb}-{ }^{84} \mathrm{Sr}$ and ${ }^{150} \mathrm{Nd}-{ }^{149} \mathrm{Sm}$ mixed spikes. Rare earth element (REE) fractions were separated using conventional cation-exchange, while $\mathrm{Nd}$ and Sm were separated through a second cation-exchange process involving 2-ethylhexyl phosphoric acid (HDEHP)-coated Teflon powder in $\mathrm{HCl}$ medium. Mass fractionations of $\mathrm{Sr}$ and $\mathrm{Nd}$ isotope ratios were normalized to ${ }^{88} \mathrm{Sr} /{ }^{86} \mathrm{Sr}=8.375209$ and ${ }^{146} \mathrm{Nd} /{ }^{144} \mathrm{Nd}=0.7219$, respectively, and these were corrected further for contributions of the spikes added. Replicate analyses of NBS987 and La Jolla standards yielded ${ }^{87} \mathrm{Sr} /{ }^{86} \mathrm{Sr}=0.710265 \pm 0.000004(2 \sigma$, $n=20)$ and ${ }^{143} \mathrm{Nd} /{ }^{144} \mathrm{Nd}=0.512099 \pm 0.000003(2 \sigma, n=20)$, respectively. Total procedural blanks showed less than 20, 100, 10, and 50 pg correspondingly for Rb, Sr, Sm, and Nd.

\section{Results}

\subsection{U-Pb Geochronology}

$\mathrm{U}-\mathrm{Pb}$ isotope data for zircons obtained from the WMC (J-13-1 and J-114-1), BIU (J17), and CIU (J-45-1, J-114-9, J-76-2, J-43-1, and J-68-1) samples were generated using the SHRIMP and LA-ICP-MS. Zircon grains from the schists and gneiss are predominantly rounded to subrounded, whereas those from the intrusive rocks are generally euhedral and prismatic. Grain sizes range between 30-300 $\mu \mathrm{m}$ for both groups of samples, while aspect ratios vary between 1:1-3:1 for the schist and gneiss samples and 1:1-4:1 for the intrusive rock samples. Spot analyses with $>\sim 1 \%$ common ${ }^{206} \mathrm{~Pb}$ or $>2500 \mathrm{ppm} \mathrm{U}$ were omitted from the age calculations. Representative CL images of the zircon grains are shown in Figure 5, while the U-Th-Pb isotopic data are presented in Tables S1 and S2.

Metamorphic rocks from the WMC display a wide range of ages. Zircon grains from the garnet-biotite schist sample (J-13-1) exhibit variable CL intensities, with prevalent oscillatory to patchy zonation and Th/U ratios between $0.01-1.31$. Twenty-one spots in 19 detrital grains yield U-Pb ages ranging from Paleoproterozoic ( 1810 Ma) to Neoproterozoic ( 700 Ma) with a pronounced Mesoproterozoic age group ( 1100-1200 Ma) (Figure 6a). Zircon grains from the hornblende gneiss sample (J-114-1) are characterized by multiple zones exhibiting dark-to-bright overgrowth rims and mantles under CL. Th/U ratios in rims (0.01-0.04) are lower than those in the inherited cores (0.11-1.84) and oscillatory zonation is common in mantles. Detrital zircon ages vary from Paleoproterozoic ( 1990 Ma) to Late Cambrian ( 530 Ma) with Mesoproterozoic ages ( 1100-1200 Ma). Younger spots in dark CL overgrowth rims yield a weighted mean ${ }^{206} \mathrm{~Pb} /{ }^{238} \mathrm{U}$ age of $502 \pm 15 \mathrm{Ma}(\mathrm{n}=4$, MSWD = 2.6), representing the metamorphic age of the hornblende gneiss (Figure $6 \mathrm{~b}$ ).

Regarding the Browning leucogranite sample (J-17), which is related to migmatization of the WMC, the zircon grains are characterized by dark CL oscillatory-zoned domains with and without bright CL cores. Six spots in 40 grains (Th/U $=0.22-0.73$ ) associated with inherited cores exhibit ages varying from 1120 to $950 \mathrm{Ma}$. After rejecting six high-U spots, oscillatory-zoned rims yield a weighted mean ${ }^{206} \mathrm{~Pb} /{ }^{238} \mathrm{U}$ age of $499.8 \pm 7.9 \mathrm{Ma}$ $(\mathrm{n}=10, \mathrm{MSWD}=5.2)$ (Figure 6c).

The CIU is associated with Early Ordovician. Zircon grains from the Campbell monzodiorite sample (J-45-1) show banded zonation and lack of inherited domains. Th/U ratios for the grains range between $0.06-2.14$ and $\mathrm{U}-\mathrm{Pb}$ isotope data yield a weighted mean ${ }^{206} \mathrm{~Pb} /{ }^{238} \mathrm{U}$ age of $479.6 \pm 4.5 \mathrm{Ma}(\mathrm{n}=20, \mathrm{MSWD}=3.0)$ (Figure $\left.6 \mathrm{~d}\right)$. 


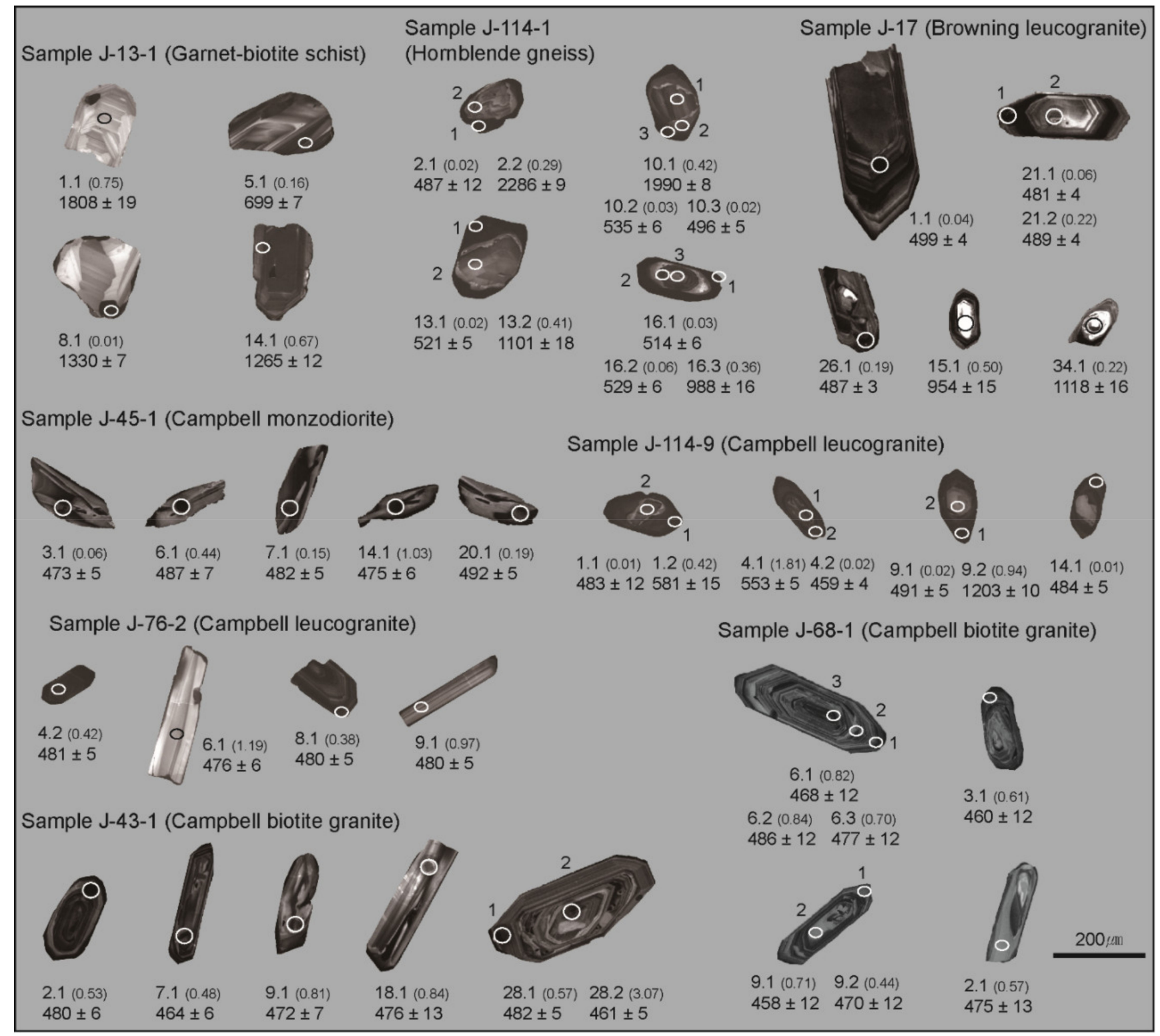

Figure 5. Representative CL images of zircons from the Wilson Metamorphic Complex and BIU-CIU. Spot numbers and apparent ${ }^{206} \mathrm{~Pb} /{ }^{238} \mathrm{U}$ ages (Ma) are stated as well as $\mathrm{Th} / \mathrm{U}$ ratios in parentheses.

The Campbell leucogranite sample (J-114-9) contains zircons characterized predominantly by low CL intensities, except for inherited cores, which show intermediate to high intensities. The latter yields U-Pb ages varying from Mesoproterozoic ( 1200 Ma) to Early Neoproterozoic $(\sim 550 \mathrm{Ma})$, with $\mathrm{Th} / \mathrm{U}$ ratios in these spots ranging between $0.21-1.81$. In dark CL rims, $\mathrm{Th} / \mathrm{U}$ ratios are low (0.01-0.03) and these produce a weighted mean ${ }^{206} \mathrm{~Pb} /{ }^{238} \mathrm{U}$ age of $482.1 \pm 8.3 \mathrm{Ma}(\mathrm{n}=15, \mathrm{MSWD}=9.0)$ that corresponds to the intrusion age of the leucogranite (J-114-9) (Figure 6e). In zircon grains from the Campbell leucogranite sample (J-76-2), oscillatory to sectoral zonation is displayed under CL, while inherited domains are scant. Th/U ratios in zoned domains or rims vary between 0.01-1.19 and the associated U-Pb isotope data yield a weighted mean ${ }^{206} \mathrm{~Pb} /{ }^{238} \mathrm{U}$ age of $479.5 \pm 4.5 \mathrm{Ma}$ $(n=5$, MSWD $=0.093)$, representing the intrusion age of the leucogranite sample $(J-76-2)$ (Figure 6f). 

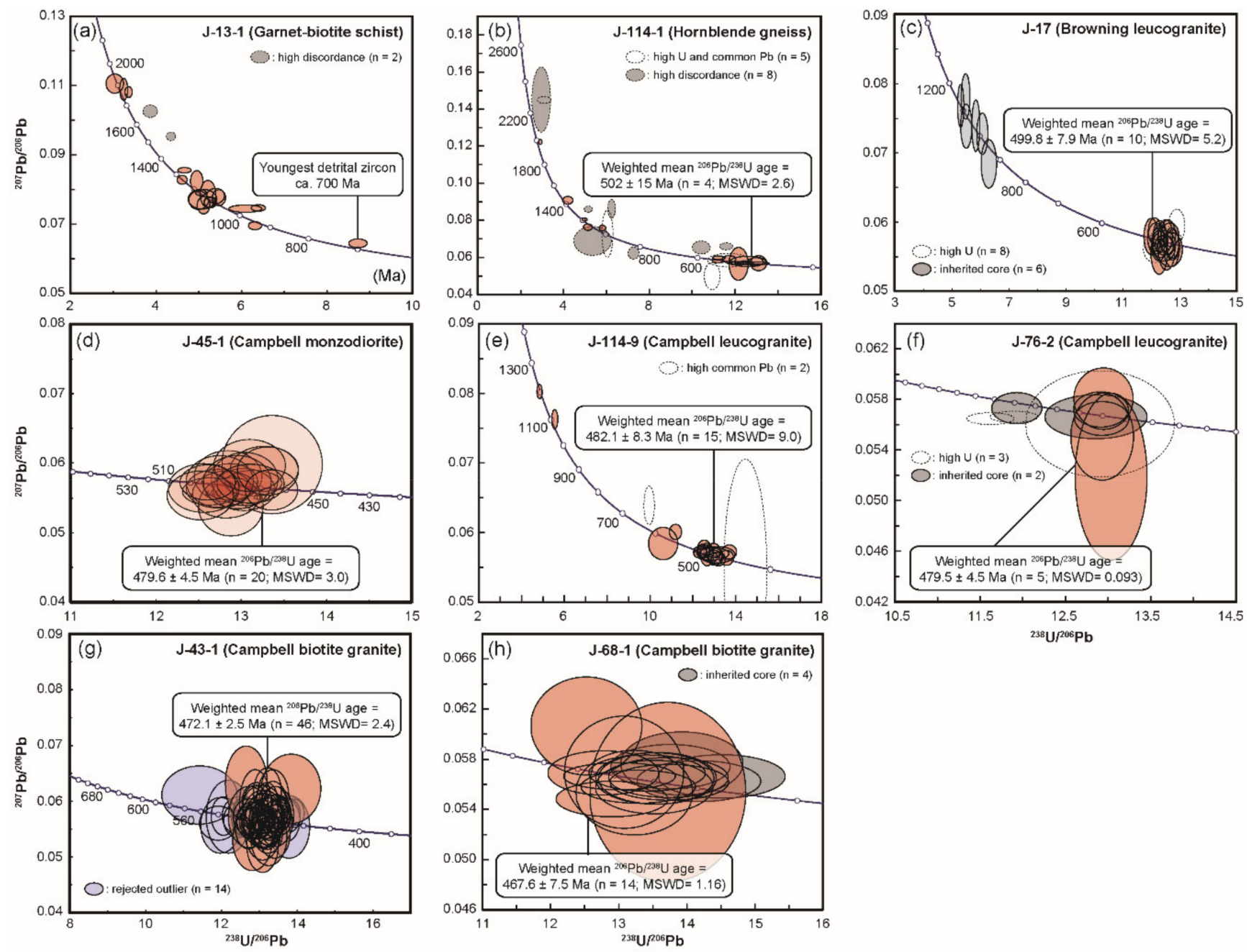

Figure 6. Tera-Wasserburg concordia diagram showing spot dates from zircon grains. Data in (a,b,e,f, $\mathbf{h})$ and $(\mathbf{c}, \mathbf{d}, \mathbf{g})$ were acquired using the SHRIMP and LA-ICP-MS, respectively. Dashed ellipses denote spot analyses excluded in the age determination because of high $\mathrm{U}$ and $\mathrm{Pb}$ contents, with discordance $>10 \%$. Error ellipses are within 2 $\sigma$. MSWD: mean square weighted deviation.

Zircon grains from the Campbell biotite granite sample (J-43-1) display oscillatory zonation with and without dark $C L$ domains, and their Th/ $\mathrm{U}$ ratios vary between $0.21-3.07$. Following the rejection of 14 outliers, oscillatory-zoned domains yield a weighted mean ${ }^{206} \mathrm{~Pb} /{ }^{238} \mathrm{U}$ age of $472.1 \pm 2.5 \mathrm{Ma}(\mathrm{n}=46, \mathrm{MSWD}=2.4)$ (Figure $\left.6 \mathrm{~g}\right)$. The Campbell biotite granite sample (J-68-1) also contains zircons grains showing oscillatory zonation with scarce inherited cores, and Th/U ratios in zoned rim vary between $0.30-0.82$. After eliminating analyses for four cores younger than rims, data for zoned domains produce a weighted mean ${ }^{206} \mathrm{~Pb} /{ }^{238} \mathrm{U}$ age of $467.6 \pm 7.5 \mathrm{Ma}(\mathrm{n}=14$, MSWD $=1.16)($ Figure $6 \mathrm{~h})$.

The U-Pb geochronology data can be summarized as follows: (1) Schist and gneiss in the WMC exhibit Late Neoproterozoic to Early Paleozoic (Early Cambrian) protolith ages and a metamorphic age of $502 \pm 15 \mathrm{Ma}$. (2) Leucogranite in the BIU reveals a formation (igneous) age of $500 \pm 8 \mathrm{Ma}$. (3) Gabbroic diorite (monzodiorite) and leucogranites in the CIU exhibit a formation age of $\sim 480 \pm 5 \mathrm{Ma}$, while biotite granites in the CIU yield igneous ages between $\sim 475-470$ Ma.

\subsection{Whole-Rock Geochemistry}

The BIU-CIU comprises mostly subalkaline rocks, which predominantly display high-K calc-alkaline characteristics (Figure 7a,b; Table S3). 


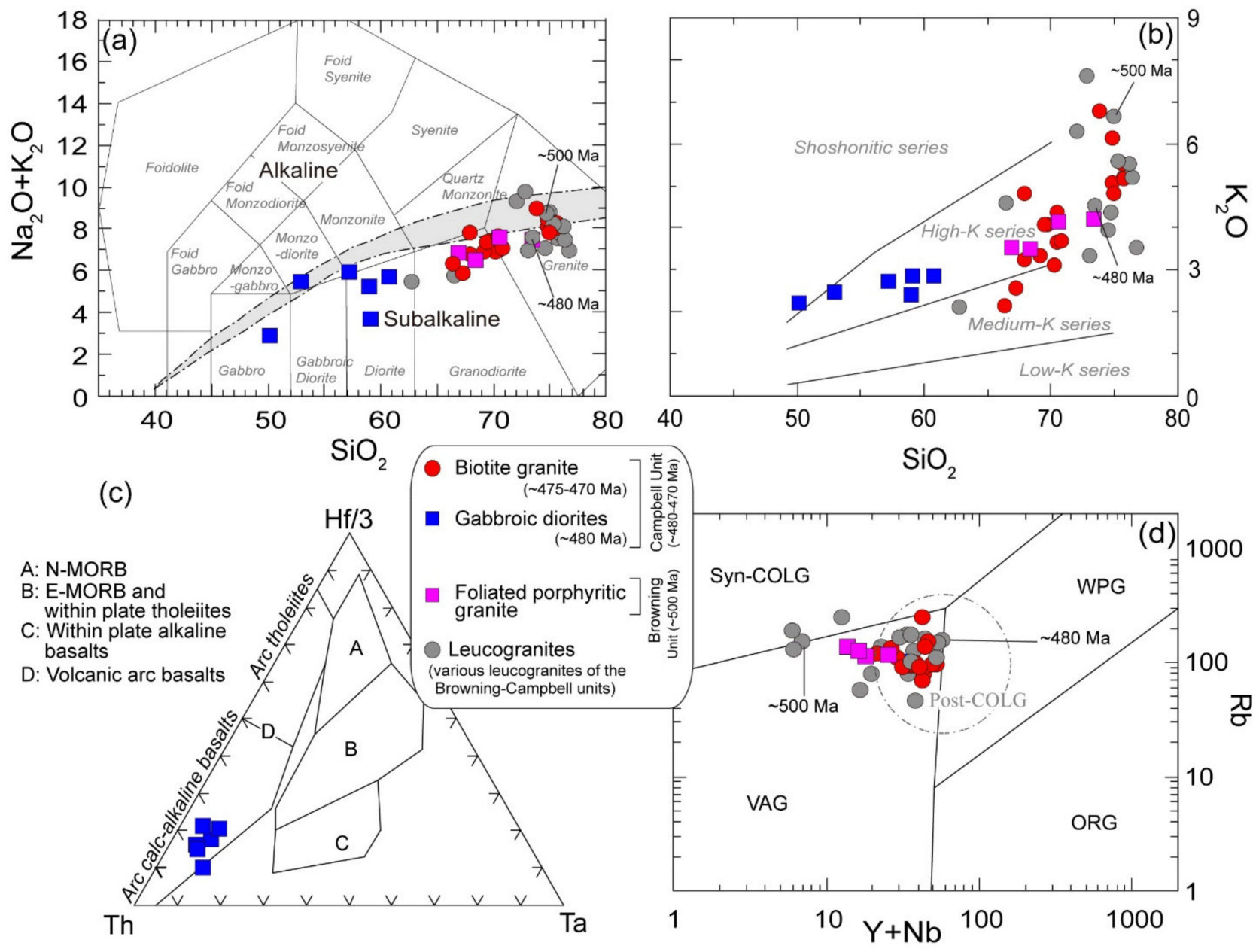

Figure 7. Classification plots showing BIU-CIU rocks in the TNIC including the (a) total alkali vs. silica (TAS) diagram (after [32]) with alkaline, transitional, and subalkaline subdivisions (after [38-41]) and (b) $\mathrm{K}_{2} \mathrm{O}$ vs. $\mathrm{SiO}_{2}$ diagram (after [24]) and tectonic discriminations in (c) Hf/3-Th-Ta ternary diagram (after [42]) and (d) Rb vs. Y+Nb diagram (after [43]). Major element concentrations in $(\mathbf{a}, \mathbf{b})$ were recalculated to $100 \mathrm{wt}$.\% on a volatile-free basis. N-MORB: normal-mid-oceanic ridge basalt; E-MORB: enriched-MORB; Syn-COLG: syn-collisional granites; Post-COLG: post-collisional granites; VAG: volcanic arc granites; WPG: within plate granites; ORG: oceanic ridge granites.

In the total alkalis vs. silica (TAS) classification scheme, foliated porphyritic granites in the BIU fall within the segment for granodiorite-granite (Figure 7a). Chondrite-normalized REE plots reveal high light REE (LREE)/heavy REE (HREE) ratios for these granites (average (ave.) $\mathrm{La} / \mathrm{Yb}_{\mathrm{N}}=68.6$ ). Particularly, three silica-rich samples (J-58, J-69, and J-70-1) show steep inclinations from the LREE to HREE $\left(\mathrm{La} / \mathrm{Yb}_{\mathrm{N}}=64-104\right)$, which highlights the presence of residual garnet in their source materials. The foliated porphyritic granites are also characterized by weak negative Eu anomalies (ave. Eu/ $\mathrm{Eu}^{*}=0.80$; Figure 8a). 

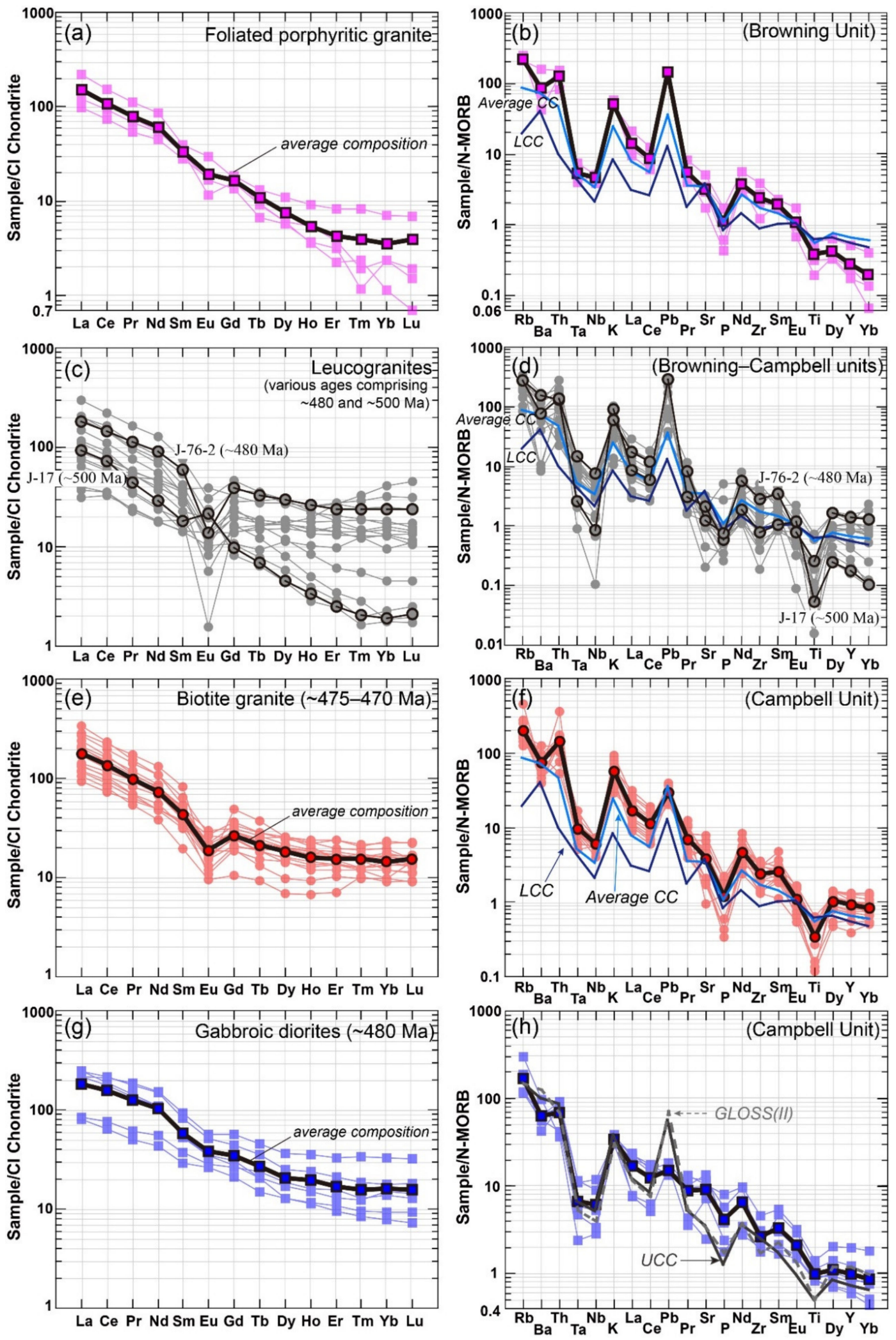

Figure 8. (a,c,e,g) Chondrite-normalized REE and (b,d,f,h) N-MORB-normalized multi-element diagrams for the BIU-CIU rocks: (a,b) Foliated porphyritic granite (BIU), (c,d) leucogranites (BIU-CIU), (e,f) biotite granite (CIU), and (g,h) gabbroic diorites (CIU). Normalization values were taken from Sun and McDonough [44], while the compositions of the average subduction zone seafloor sediment (global subducting sediment, GLOSS-II) and continental crust are taken from Plank [45] and Rudnick and Gao [46], respectively. CC: continental crust; LCC: lower continental crust; UCC: upper continental crust. 
At least two types of leucogranites are identified in the study area and these include: the Browning leucogranites associated with migmatization of the WMC and/or intrusion of the complex and a later leucogranite assigned to the CIU. Based on compositional data, these leucogranites mostly fall within the segment for granite in the TAS classification scheme, with some samples exhibiting granodiorite and diorite compositions (Figure 7a). Chondrite-normalized REE plots for leucogranites display various patterns, with wideranging $\mathrm{La} / \mathrm{Yb}_{\mathrm{N}}$ ratios $(2.02-59.21)$ and both negative and positive $\mathrm{Eu}$ anomalies $\left(\mathrm{Eu} / \mathrm{Eu}^{*}=0.09-2.15\right)$, which indicate that these samples originate from diverse plutons. A sample (J-17, BIU) age-confirmed shows positive Eu anomaly and HREE depletion, while another age-confirmed sample (J-76-2, CIU) exhibits negative Eu anomaly and higher REE contents (Figure 8c).

Biotite granites in the CIU exhibit granodiorite-granite compositions in the TAS classification scheme (Figure 7a). Chondrite-normalized REE plots reveal high LREE/HREE ratios (ave. $\mathrm{La} / \mathrm{Yb}_{\mathrm{N}}=13.23$ ) and distinct negative $\mathrm{Eu}$ anomalies (ave. $\mathrm{Eu} / \mathrm{Eu}^{*}=0.56$ ) for these granites. The plots show flat HREE variation or slight inclination from the middle REE (MREE) to HREEs (Figure 8e).

In the normal mid-ocean ridge basalt (N-MORB)-normalized multi-element diagram, granitoids of the BIU-CIU exhibit variations highlighting high large ion lithophile element (LILE)/high field strength element (HFSE) ratios. These samples are also characterized by negative Ta- $\mathrm{Nb}, \mathrm{P}$, and $\mathrm{Ti}$ values and elevated $\mathrm{K}$ and $\mathrm{Pb}$ (Figure $8 \mathrm{~b}, \mathrm{~d}, \mathrm{f}$ ). These patterns, which are similar to that of the average continental crust [46], suggest that the source materials of granitoids in the BIU-CIU originated predominantly from the continental crust.

Gabbroic to dioritic samples in the CIU show compositions for gabbro, monzodiorite, monzonite, and diorite (Figure 7a) within a limited outcrop, and thus, these are considered comagmatic. These gabbroic diorites display distinct slopes from LREEs to HREEs (ave. $\left.\mathrm{La} / \mathrm{Yb}_{\mathrm{N}}=12.7\right)$ in chondrite-normalized plots and weak negative or no Eu anomaly (ave. $\mathrm{Eu} / \mathrm{Eu}^{*}=0.89$ ) (Figure 8g). In N-MORB-normalized multi-element diagrams, these gabbroic diorites also display high LILE/HFSE characteristics, negative $\mathrm{Ta}-\mathrm{Nb}, \mathrm{Pb}, \mathrm{Zr}$, and $\mathrm{Ti}$ values, and positive $\mathrm{K}$ and $\mathrm{Pb}$ values (weak $\mathrm{Pb}$ spike). This pattern is similar to that of the average subduction zone seafloor sediment (global subducting sediment composite, GLOSS-II: [45]) or the upper continental crust (UCC: [46]) (Figure 8h). This suggests that terrigenous components were involved in producing primitive basaltic magmas from which the gabbroic diorites were derived (see Section 6.1).

In a tectonic discrimination diagram, gabbroic diorites of the CIU mostly show similarities to volcanic arc calc-alkaline basalts. Granitoids in the BIU-CIU predominantly display resemblance to volcanic arc granites, yet granites of the CIU especially show characteristics akin to post-collisional tectonic environments (Figure 7c,d).

Whole-rock initial ${ }^{87} \mathrm{Sr} /{ }^{86} \mathrm{Sr}\left({ }^{87} \mathrm{Sr} /{ }^{86} \mathrm{Sr}_{(\mathrm{i})}\right)$ and $\varepsilon \mathrm{Nd}_{(\mathrm{t})}$ data for BIU-CIU rocks are characterized by distinct compositions for each unit, which suggest differences in their source components (Figure 9 and Table 1). Two gabbroic diorite samples (J-45-1 and J-57) from the CIU exhibited ${ }^{87} \mathrm{Sr} /{ }^{86} \mathrm{Sr}_{(\mathrm{i})}$ ratios varying from 0.704714 to 0.704900 and $\varepsilon \mathrm{Nd}_{(\mathrm{t})}$ values of 1.58 to 1.76 , which indicate mantle-sourced components, whereas a diorite sample (J-46-1) revealed distinct evolution, with an ${ }^{87} \mathrm{Sr} /{ }^{86} \mathrm{Sr}_{(\mathrm{i})}$ ratio of 0.709548 and $\varepsilon \mathrm{Nd}_{(\mathrm{t})}$ value of -7.49 . A similar distinction is evident for the Campbell biotite granites, with a biotite granite sample (J-44-1, granodiorite composition) showing ${ }^{87} \mathrm{Sr} /{ }^{86} \mathrm{Sr}_{(\mathrm{i})}$ and $\varepsilon \mathrm{Nd}_{(\mathrm{t})}$ values of 0.704286 and 1.40, respectively, whereas a silica-rich biotite granite sample (J43-1) showed evolved crustal values of 0.705158 and -4.01 , respectively. In addition, a leucogranite sample $(\mathrm{J}-7-3)$ produced an ${ }^{87} \mathrm{Sr} /{ }^{86} \mathrm{Sr}_{(\mathrm{i})}$ ratio of 0.708767 and an $\varepsilon \mathrm{Nd}_{(\mathrm{t})}$ value of -6.47 . An ${ }^{87} \mathrm{Sr} /{ }^{86} \mathrm{Sr}_{(\mathrm{i})}$ ratio of 0.713050 and an $\varepsilon \mathrm{Nd}_{(\mathrm{t})}$ value of -8.88 were obtained from a Browning foliated porphyritic granite (J-58), and these suggest an evolved crustal source component. A leucogranite sample (J-12-2) linked to migmatization of the WMC showed a highly evolved ${ }^{87} \mathrm{Sr} /{ }^{86} \mathrm{Sr}_{(\mathrm{i})}$ ratio $(0.723202)$ and $\varepsilon \mathrm{Nd}_{(\mathrm{t})}$ value $(-8.67)$, and these roughly overlap with values for the migmatitic gneisses $\left({ }^{87} \mathrm{Sr} /{ }^{86} \mathrm{Sr}_{(500 \mathrm{Ma})}=\sim 0.7190-0.7200\right.$ and $\varepsilon \mathrm{Nd}_{(500 \mathrm{Ma})}=-10.5$ to -10.8$)$ of the WMC. 


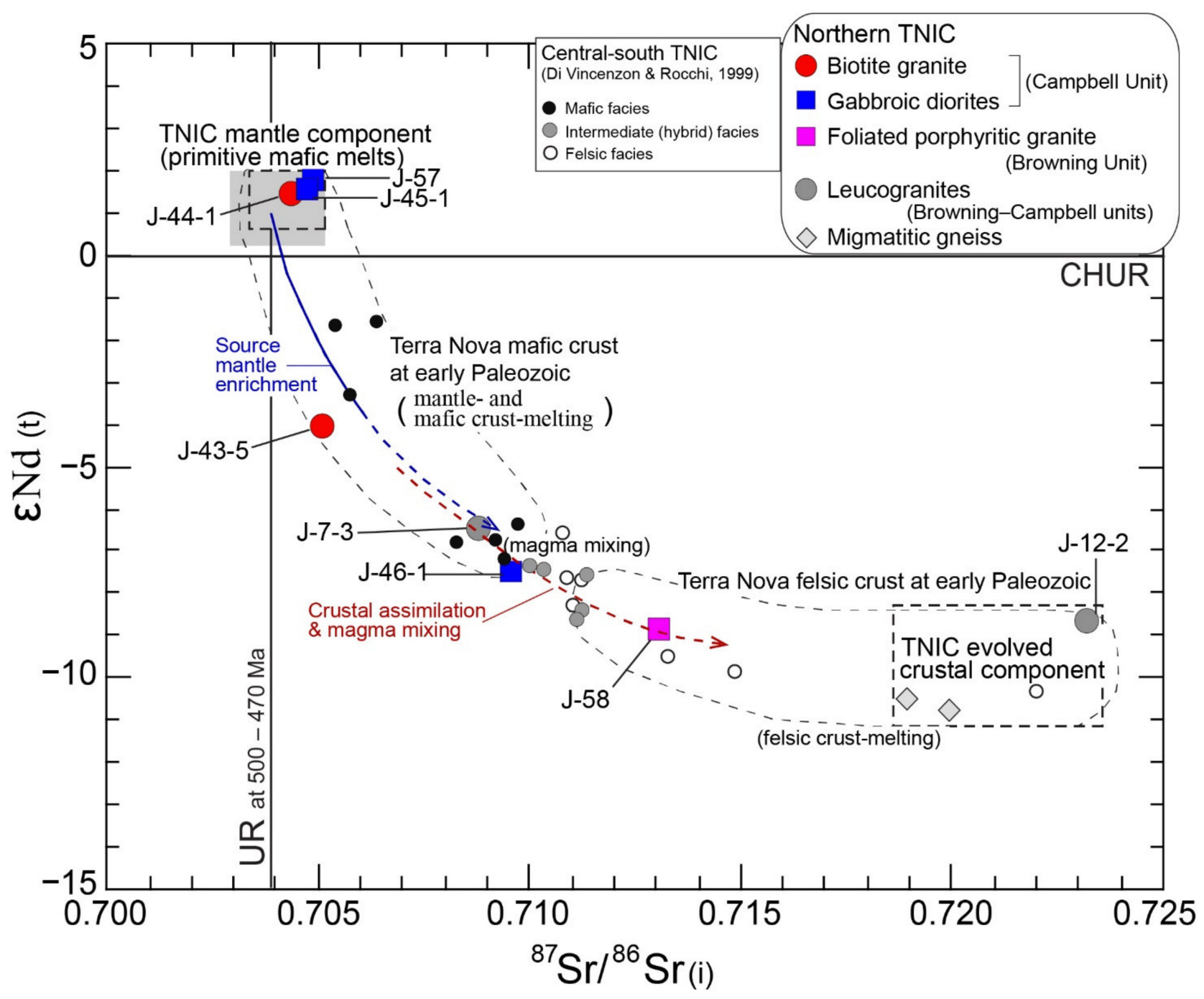

Figure 9. Whole-rock ${ }^{87} \mathrm{Sr} /{ }^{86} \mathrm{Sr}_{(\mathrm{i})}$ vs. $\varepsilon \mathrm{Nd}_{(\mathrm{t})}$ plot for the BIU-CIU samples. Reference data for the south-central TNIC are taken from Di Vincenzo and Rocchi [12]. The TNIC mantle component was estimated based on data in the present and previous studies [12,13]. Present-day ${ }^{147} \mathrm{Sm} /{ }^{144} \mathrm{Nd}(0.1967)$ and ${ }^{143} \mathrm{Nd} /{ }^{144} \mathrm{Nd}(0.512638)$ ratios of the chondritic uniform reservoir (CHUR) are from Wasserburg et al. [47] and DePaolo [48]. Present-day ${ }^{87} \mathrm{Rb} /{ }^{86} \mathrm{Sr}(0.0827)$ and ${ }^{87} \mathrm{Sr} /{ }^{86} \mathrm{Sr}(0.7045)$ ratios of the undifferentiated reservoir (UR) are from DePaolo [48] and Faure [49].

In summary, the Campbell gabbroic diorites show initial Sr-Nd ratio characteristics of mantle components, and a Campbell biotite granite sample (J-44-1) displayed similar values. Diorite (J-46-1), biotite granite (J-43-5), foliated porphyritic granite (J-58), and leucogranite samples of the BIU-CIU show enriched initial Sr-Nd ratios, with the leucogranite sample (J-12-2) linked to migmatization of the WMC exhibiting the most enrichment in crustal components (Figure 9). Incompatible trace element contents of the gabbro-granites of the BIU-CIU produce similar patterns in an N-MORB-normalized multi-element diagram, and these patterns resemble those of samples with continental crust components (Figure 8). This suggests that the continental crust component was significantly involved during partial melting of the mantle and later acted as the main source of magma for the granitoids. 
Table 1. Sr-Nd isotopic data for the BIU-CIU rocks in the TNIC, northern Victoria Land.

\begin{tabular}{|c|c|c|c|c|c|c|c|c|c|c|c|}
\hline Sample & Rock Type & $\begin{array}{l}\text { Lithologic } \\
\text { Unit }\end{array}$ & ${ }^{87} \mathrm{Rb} /{ }^{86} \mathrm{Sr}$ & ${ }^{87} \mathrm{Sr} /{ }^{86} \mathrm{Sr}$ & $2 \sigma$ & ${ }^{87} \mathrm{Sr} /{ }^{86} \mathrm{Sr}_{(\mathrm{i})}$ & ${ }^{147} \mathrm{Sm} /{ }^{144} \mathrm{Nd}$ & ${ }^{143} \mathrm{Nd} /{ }^{144} \mathrm{Nd}$ & $2 \sigma$ & ${ }^{143} \mathrm{Nd} /{ }^{144} \mathrm{Nd}_{(\mathrm{i})}$ & $\varepsilon \mathbf{N d}_{(t)}$ \\
\hline$J-43-5$ & Biotite & \multirow{2}{*}{ CIU } & 1.80495 & 0.717245 & 0.000012 & 0.705158 & 0.10093 & 0.512138 & 0.000007 & 0.511827 & -4.01 \\
\hline J-44-1 & granite & & 0.41780 & 0.707084 & 0.000009 & 0.704286 & 0.09378 & 0.512393 & 0.000007 & 0.512104 & 1.40 \\
\hline J-45-1 & \multirow{3}{*}{$\begin{array}{l}\text { Gabbroic } \\
\text { diorites }\end{array}$} & \multirow{3}{*}{ CIU } & 0.21733 & 0.706200 & 0.000009 & 0.704714 & 0.11081 & 0.512449 & 0.000006 & 0.512101 & 1.58 \\
\hline J-46-1 & & & 0.79927 & 0.715014 & 0.000008 & 0.709548 & 0.12345 & 0.512024 & 0.000007 & 0.511636 & -7.49 \\
\hline $\mathrm{J}-57$ & & & 0.26677 & 0.705749 & 0.000010 & 0.704900 & 0.09269 & 0.512401 & 0.000008 & 0.512110 & 1.76 \\
\hline $\mathrm{J}-58$ & $\begin{array}{c}\text { Foliated } \\
\text { porphyritic } \\
\text { granite }\end{array}$ & BIU & 2.70148 & 0.732299 & 0.000010 & 0.713050 & 0.11659 & 0.511921 & 0.000007 & 0.511539 & -8.88 \\
\hline $\mathrm{J}-7-3$ & Jeurcorranite & & 1.50378 & 0.719052 & 0.000009 & 0.708767 & 0.11344 & 0.512045 & 0.000006 & 0.511688 & -6.47 \\
\hline $\mathrm{J}-12-2$ & Leucogranite & BIU-CIU & 1.72002 & 0.735458 & 0.000010 & 0.723202 & 0.16922 & 0.512104 & 0.000012 & 0.511550 & -8.67 \\
\hline $\mathrm{J}-26-2$ & Migmatitic & & 2.75044 & 0.738528 & 0.000009 & 0.718930 & 0.10899 & 0.511811 & 0.000007 & 0.511454 & -10.54 \\
\hline $\mathrm{J}-28$ & gneiss & WMC & 2.29805 & 0.736266 & 0.000010 & 0.719892 & 0.11170 & 0.511808 & 0.000007 & 0.511442 & -10.77 \\
\hline
\end{tabular}

Isotopic compositions of $\mathrm{Sr}$ and $\mathrm{Nd}$ were normalized to ${ }^{86} \mathrm{Sr} /{ }^{88} \mathrm{Sr}=0.1194$ and ${ }^{146} \mathrm{Nd} /{ }^{144} \mathrm{Nd}=0.7219$, respectively. $\varepsilon N d(t)=\left[\left({ }^{143} \mathrm{Nd} /{ }^{144} \mathrm{Nd}\right)_{\text {sample }, \mathrm{t}} /\left({ }^{143} \mathrm{Nd} /{ }^{144} \mathrm{Nd}\right)_{\mathrm{CHUR}, \mathrm{t}}-1\right] \times 10^{4} .\left({ }^{147} \mathrm{Sm} /{ }^{144} \mathrm{Nd}\right)_{\mathrm{CHUR}}=0.1967,\left({ }^{143} \mathrm{Nd} /{ }^{144} \mathrm{Nd}\right)_{\mathrm{CHUR}}=0.512638 ;[47,48]$. $\lambda_{87 \mathrm{Rb}}=1.42 \times 10^{-11} / \mathrm{yr}$ [50]; $\lambda_{147 \mathrm{Sm}}=6.54 \times 10^{-12} / \mathrm{yr}$ [51]. Initial isotopic ratios of the migmatitic gneiss (WMC) were calculated to be an age of $500 \mathrm{Ma}$.

\section{Discussion}

As mentioned in Sections 3 and 5, the igneous activity in the study area is characterized by continuous and various compositional (mantle and crustal source components) magma intrusions, which have an age range between 500 and $470 \mathrm{Ma}$. This result may reflect the continental arc orogeny process of the northern TNIC. Thus, we intend to discuss the Paleozoic crustal evolution of the entire TNIC based on our isotopic and age data combined with literature data. First, based on the Sr-Nd isotope components of the TNIC, we consider the crustal formation of the TNIC, and then, we discuss the formation of the TNIC from the temporal and tectonic perspectives.

\subsection{Magma Sources of the BIU-CIU in the TNIC}

In Section 5, the trace element contents and Sr-Nd isotope characteristics of gabbroic diorites and granitoids were presented. In the N-MORB-normalized multi-element diagram, gabbroic diorites show negative troughs for $\mathrm{Ta}-\mathrm{Nb}, \mathrm{P}$, and Ti and positive spikes for $\mathrm{K}$ and $\mathrm{P}$, which are characteristics similar to those obtained for the average trench sediment (GLOSS-II: [45]) and the UCC [46] (Figure 8). These characteristics, which are typically displayed by arc basalts or arc basaltic andesites, are explained by the following processes: (1) a mantle wedge acquired a terrestrial signature through metasomatism involving partial melting of subducting terrigenous sediments or fluid dehydration of the subducting plate and (2) arc igneous rocks inherited crust-like geochemical characteristics from the metasomatized mantle wedge (e.g., [52-57]). Regarding the Campbell gabbroic diorite samples $\left(\mathrm{J}-45-1\right.$ and J-57), their initial Sr-Nd data ${ }^{87} \mathrm{Sr} /{ }^{86} \mathrm{Sr}_{(\mathrm{i})}=0.7047-0.7049$ and $\varepsilon \mathrm{Nd}_{(\mathrm{t})}=1.6$ to 1.8) possibly reflect characteristics of the mantle source. However, a Campbell diorite sample (J-46-1) exhibits an evolved crustal signature ${ }^{87} \mathrm{Sr} /{ }^{86} \mathrm{Sr}_{(\mathrm{i})}=0.7095$ and $\left.\varepsilon \mathrm{Nd}_{(\mathrm{t})}=-7.5\right)$ (Figure 9). This crustal signature can be attributed to the following: (1) a highly enriched mantle signature, (2) crustal assimilation linked to emplacement of the primitive basaltic magma, or (3) mixing of basaltic and granitic melt components. Scenarios presented in 2 and 3 were advanced previously for the TNIC [12,13].

Enriched mantle isotope signatures (scenario 1) have been reported in many subductionrelated mafic to intermediate igneous rocks (e.g., [58-63]). The source materials of these igneous rocks are generally assigned to a lithospheric mantle enriched during subduction, and the associated igneous rocks are representative of continental arc and post-arc settings (e.g., [58-60,62,64,65]. Monzodiorites previously reported in the TNIC (especially the mafic series of the Vegetation Unit) exhibit enriched isotopic signature $\left(\varepsilon \mathrm{Nd}_{(\mathrm{t})}=-6.8\right.$ to -7.3$)$ (Figure 9) [12]. Thus, a primitive basaltic magma produced in the isotopically enriched mantle $\left(\varepsilon \mathrm{Nd}_{(\mathrm{t})}<-6.0\right)$ might have differentiated into monzodiorite-diorite magmas in the TNIC. However, the primitive basaltic magma could have evolved into a dioritic magma via crustal assimilation during its ascent into the continental Wilson Terrane. 
A two-stage magma evolution model (scenario 2-3) for the central-south TNIC involving crustal assimilation and magma mixing has been proposed [12,13]. According to this model, mafic-intermediate-felsic intrusives in the TNIC originate from the interaction of mantle melts, crustal melts, and the crust. In other words, the primitive mantle melt evolved through crustal assimilation (stage 1) and mixed with a crustal felsic melt (stage 2) to produce an intrusive complex of varying composition in the Terra Nova Bay area. Isotopic characteristics of mafic-intermediate-felsic igneous rocks in the BIU-CIU, which represent the northern TNIC appear to also follow the evolutionary stages of the two-stage model (Figure 9). However, because mafic-intermediate magmas characterized by isotopic enrichment without distinct crustal assimilation have been reported in many continental arcs, the possibility of a highly enriched mantle source (e.g., enriched subcontinental lithospheric mantle) for the TNIC intrusives also deserves attention. This requires isotope studies of the TNIC (monzo)gabbro.

Granitoids of the BIU-CIU exhibit wide-ranging ${ }^{87} \mathrm{Sr} /{ }^{86} \mathrm{Sr}_{(\mathrm{i})}(0.7043-0.7232)$ and $\varepsilon \mathrm{Nd}_{(\mathrm{t})}$ $(1.4$ to -8.9$)$ values. The positive $\varepsilon \mathrm{Nd}_{(\mathrm{t})}$ value (1.4) for the Campbell biotite granite sample (J-44-1) suggests an association with mantle components. However, characteristics of incompatible trace elements for the Campbell biotite granites indicate a dominance of crustal components (Figure 8d,f). Therefore, a young (e.g., Cambrian) mafic intrusive rock is a potential dominant source material for the Campbell biotite granites because a young mafic crust retains its source mantle isotopic characteristics. In addition, if the source material is attributed to a rock of Cambrian age, this will most likely be a mafic intrusive associated with the early phase of the Ross Orogeny. The highly enriched crustal values $\left({ }^{87} \mathrm{Sr} /{ }^{86} \mathrm{Sr}_{(\mathrm{i})}=0.7189-0.7232 ; \varepsilon \mathrm{Nd}_{(\mathrm{t})}=-8.7\right.$ to -10.8$)$ for the leucogranite sample (J-12-2) and the surrounding migmatitic gneisses probably reflect the felsic crust (or upper crust) composition of the TNIC in Early Paleozoic. Based on these relationships, samples J-43-5 and J-7-3 probably formed from partial melting of the dominantly mafic crust source. Whereas, the enriched Sr-Nd isotope characteristics of sample J-58 suggest a mafic crustderived melt that assimilated felsic crust or was mixed with felsic crust-derived melt and/or a felsic crust-derived melt itself.

Therefore, the following isotopic model is proposed: The sub-TNIC mantle in Early Paleozoic (Cambro-Ordovician) involved component with $\varepsilon \mathrm{Nd}_{(\mathrm{t})}$ of $1-2$ or $<1$ (e.g., Campbell gabbroic diorites J-45-1 and J-57 and [12,13]). In the Early Paleozoic, the TNIC mafic crust (or lower crust) was associated with ${ }^{87} \mathrm{Sr} /{ }^{86} \mathrm{Sr}_{(\mathrm{t})}$ ratios of $0.704-0.710$ and $\varepsilon \mathrm{Nd}_{(\mathrm{t})}$ values from 1 to -7 (e.g., mafic facies of the TNIC) reflecting a subdominant component of the sub-TNIC mantle. Conversely, the felsic crust (or upper crust) was more enriched $\left({ }^{87} \mathrm{Sr} /{ }^{86} \mathrm{Sr}_{(\mathrm{t})}=0.711-0.723\right.$ and $\varepsilon \mathrm{Nd}_{(\mathrm{t})}=-8$ to -11 ; e.g., felsic facies of the TNIC). Therefore, the magmatism during $~ 500-470 \mathrm{Ma}$ in the TNIC is attributed to partial melting of the mantle, mafic crust, and felsic crust, the interaction of these melts with the crusts, and magma mixing (Figure 9).

\subsection{Tectonic Environment for the TNIC Magmatism}

Tectonic interpretations for the formation of NVL from the Ross Orogeny have been advanced based on strike-slip movements, geochemical characteristics of the volcanics and granitoids, and sedimentary events [22,66-69]. Kleinschmidt and Tessensohn [70] proposed a tectonic model involving two parallel westward-dipping subduction zones. This model can be summarized in the following steps: (1) An island arc (the Glasgow volcanics) formed earlier in an intraoceanic region was transported toward the continental Wilson Terrane between 530 and 500 Ma. (2) During the Ross Orogeny, widespread granitization mainly occurred at $\sim 500 \mathrm{Ma}$, and this was accompanied by deformation events until $480 \mathrm{Ma}$. (3) Devonian granitoids and related volcanics were then formed after a long tectonic lull. In subsequent models, the possible formation of a continental arc at 530-520 Ma and a continent-continent collision at $\sim 500-490$ Ma [71-73] were proposed.

Our geochronological and geochemical data reveal two distinct magmatic ages of $\sim 500 \mathrm{Ma}$ for the BIU and $\sim 480-470 \mathrm{Ma}$ for the CIU, which reflect the complete magma evolu- 
tion especially for mantle components (Figure 9) $[12,13]$. Based on these data, magmatism in the Wilson Terrane margin in NVL can be reconstructed. During the Early Cambrian, calc-alkaline granitoids associated with eclogite-facies metamorphism were emplaced at $\sim 530 \mathrm{Ma}$, and this indicates an active continental margin existed at $530-520 \mathrm{Ma}[2,74,75]$. The wide-ranging magmatic/metamorphic zircon ages from the studied schists imply a continuous supply of detrital materials in the Early Cambrian [76]. During the Late Cambrian, widespread magmatism and migmatization occurred due to a subduction of the Paleo-Pacific Plate or a continent-arc (i.e., Wilson Terrane-Bowers Terrane) collision (e.g., [77]). The compressional regime of the Ross Orogeny produced numerous intrusive bodies, such as the Confusion ( 526-513 Ma), Browning ( 500 Ma), and Abbott ( 495 Ma) units, which are possibly of intermediate to extensive depths, in the TNIC. During Early Ordovician, the Ross Orogeny experienced a transitional regime toward post-collisional (or post-orogenic) extension, and the Inexpressible Syenite ( 485 Ma) and Campbell ( $\sim 480-470 \mathrm{Ma})$ and Vegetation ( 475 Ma) units, likely associated with shallow depths, were formed in the TNIC (Figure 2) (e.g., [23,71,78,79]). Therefore, the TNIC magmatism at $\sim 510-470$ Ma characterized by distinctively wide-ranging ${ }^{87} \mathrm{Sr} /{ }^{86} \mathrm{Sr}_{(\mathrm{i})}$ and $\varepsilon \mathrm{Nd}_{(\mathrm{t})}$ values could reflect its various magmatic sources and a changing tectonic environment in NVL.

\section{Conclusions}

In the present study, we conducted geochronological and geochemical investigations of igneous rocks from the northern TNIC in NVL, Antarctica, and the main findings are as follows:

1. Two distinct intrusive units are identified in the TNIC. The BIU (Late Cambrian) originates from arc crustal melting, and also is contributed to the migmatization of the WMC. The CIU (Early Ordovician), which comprises later igneous bodies, is attributed to mantle-derived melts intrusions and associated crustal anatexis.

2. Gneiss and schist in the WMC exhibit Late Neoproterozoic to Early Paleozoic (Early Cambrian) protolith ages and a metamorphic age of $502 \pm 15 \mathrm{Ma}$. A leucogranite from the BIU reveals the emplacement age of $500 \pm 5$ Ma which is synchronous with the metamorphism of the WMC. Relatedly, gabbroic diorites and leucogranites from the CIU produce ages of $\sim 480 \pm 5 \mathrm{Ma}$, while biotite granite (later intrusive in the CIU) samples yield igneous ages between $\sim 475-470 \mathrm{Ma}$.

3. Sr-Nd isotopic characteristics of the BIU-CIU display both the Ross orogenic mantlemafic crust $\left({ }^{87} \mathrm{Sr} /{ }^{86} \mathrm{Sr}_{(500-470 \mathrm{Ma})}=0.7043-0.7049\right.$ and $\varepsilon \mathrm{Nd}_{(500-470 \mathrm{Ma})}=1.4$ to 1.8$)$ and felsic crust $\left({ }^{87} \mathrm{Sr} /{ }^{86} \mathrm{Sr}_{(500-470 \mathrm{Ma})}=0.7189-0.7232\right.$ and $\varepsilon \mathrm{Nd}_{(500-470 \mathrm{Ma})}=-8.7$ to -10.8$)$ compositions as well as their mixing combinations.

4. The distinct wide range of ${ }^{87} \mathrm{Sr} /{ }^{86} \mathrm{Sr}_{(\mathrm{i})}$ and $\varepsilon \mathrm{Nd}_{(\mathrm{t})}$ associated with the BIU-CIU are attributed to mantle and mafic crust melting, crustal assimilation, subsequent felsic crust melting, and magma mixing, which are processes typical in continental arcs. These processes well explain the Ross orogenic arc crustal building of the TNIC in NVL.

Supplementary Materials: The following are available online at https:/ /www.mdpi.com/article/10 $.3390 / \mathrm{min} 11070787 / \mathrm{s} 1$ : Table S1. SHRIMP zircon U-Pb isotopic data for samples from the northern TNIC, NVL, Antarctica; Table S2. LA-ICP MS zircon U-Pb isotopic data for samples from the northern TNIC, NVL, Antarctica; Table S3. Representative whole-rock major and trace element data for BIU-CIU rocks in the northern TNIC, NVL, Antarctica. 
Author Contributions: This work is generated from the Korean Antarctic Research Program based at the Jang Bogo Station led by D.K. and H.K. during the 2016-2018 austral summer seasons. Conceptualization, D.K., S.-B.Y., H.K.; investigation and data curation, H.K. and T.K. (Taehoon Kim); writing-original draft preparation, D.K., S.-B.Y., H.K., T.K. (Taehwan Kim); writing-review and editing, all authors; funding acquisition, J.I.L. All authors have read and agreed to the published version of the manuscript.

Funding: This work was supported by the KOPRI project PE21050 and the principal Research Fund of Korea Institute of Geoscience and Mineral Resources (GP2021-006:21-3122).

Data Availability Statement: The data presented in this study are available in the Supplementary Materials.

Acknowledgments: Fieldworks were supported by Donghwa Kim and Se Hoon Lim (Outward Bound Korea). Ijeung Kim and Pil-Mo Kang are thanked for supporting the CL image process. Three anonymous reviewers are appreciated for their constructive comments. We thank journal editors for their guidance and handling of the manuscript.

Conflicts of Interest: The authors declare no conflict of interest.

\section{References}

1. Finn, C.; Moore, D.; Damaske, D.; Mackey, T. Aeromagnetic legacy of early Paleozoic subduction along the Pacific margin of Gondwana. Geology 1999, 27, 1087-1090. [CrossRef]

2. Godard, G.; Palmeri, R. High-pressure metamorphism in Antarctica from the Proterozoic to the Cenozoic: A review and geodynamic implications. Gondwana Res. 2013, 23, 844-864. [CrossRef]

3. Boger, S.D.; Wilson, C.J.L.; Fanning, C.M. Early Paleozoic tectonism within the East Antarctic craton: The final suture between east and west Gondwana? Geology 2001, 29, 463-466. [CrossRef]

4. Meert, J.G. A synopsis of events related to the assembly of eastern Gondwana. Tectonophysics 2003, 362, 1-40. [CrossRef]

5. Boger, S.D.; Miller, J.M. Terminal suturing of Gondwana and the onset of the Ross-Delamerian Orogeny: The cause and effect of an Early Cambrian reconfiguration of plate motions. Earth Planet. Sci. Lett. 2004, 219, 35-48. [CrossRef]

6. Boger, S.D. Antarctica-Before and after Gondwana. Gondwana Res. 2011, 19, 335-371. [CrossRef]

7. Torsvik, T.H.; Cocks, L.R.M. Gondwana from top to base in space and time. Gondwana Res. 2013, 24, 999-1030. [CrossRef]

8. Fitzsimons, I.C.W. A review of tectonic events in the East Antarctic Shield and their implications for Gondwana and earlier supercontinents. J. Afr. Earth Sci. 2000, 31, 3-23. [CrossRef]

9. Harley, S.L. Archaean-Cambrian crustal development of East Antarctica: Metamorphic characteristics and tectonic implications. Geol. Soc. Lond. Spec. Publ. 2003, 206, 203-230. [CrossRef]

10. Dalziel, I.W.D. Overview: Neoproterozoic-Paleozoic geography and tectonics: Review, hypothesis, environmental speculation. Geol. Soc. Am. Bull. 1997, 109, 16-42. [CrossRef]

11. Cawood, P.A. Terra Australis Orogen: Rodinia breakup and development of the Pacific and Iapetus margins of Gondwana during the Neoproterozoic and Paleozoic. Earth Sci. Rev. 2005, 69, 249-279. [CrossRef]

12. Di Vincenzo, G.; Rocchi, S. Origin and interaction of mafic and felsic magmas in an evolving late orogenic setting: The Early Paleozoic Terra Nova Intrusive Complex, Antarctica. Contrib. Mineral. Petr. 1999, 137, 15-35. [CrossRef]

13. Rocchi, S.; Di Vincenzo, G.; Ghezzo, C. The Terra Nova Intrusive Complex (Victoria Land, Antarctica); Terra Antarctic Reports; Terra Antarctic Publication: Genova, Italy, 2004; Volume 10, p. 50.

14. Rocchi, S.; Tonarini, S.; Armienti, P.; Innocenti, F.; Manetti, P. Geochemical and isotopic structure of the early Palaeozoic active margin of Gondwana in northern Victoria Land, Antarctica. Tectonophysics 1998, 284, 261-281. [CrossRef]

15. Kim, H.; Kim, D.; Lee, J.I.; Woo, J.; Koh, H.J.; Lee, S.-R. Geologic Map around the Jang Bogo Station, Northern Victoria Land, Antarctica 1:20,000; Project Publication of the Korea Polar Research Institute and Ministry of Ocean and Fisheries: Seoul, Korea, 2018.

16. Elliot, D.H. The geological and tectonic evolution of the Transantarctic Mountains: A review. Geol. Soc. Lond. Spec. Publ. 2013, 381, 7. [CrossRef]

17. Goodge, J.W. Geological and tectonic evolution of the Transantarctic Mountains, from ancient craton to recent enigma. Gondwana Res. 2020, 80, 50-122. [CrossRef]

18. Stump, E. The Ross Orogen of the Transantarctic Mountains; Cambridge University Press: Cambridge, UK, 2010.

19. Armienti, P.; Ghezzo, C.; Innocenti, F.; Manetti, P.; Rocchi, S.; Tonarini, S. Isotope geochemistry and petrology of granitoid suites from Granite Harbour Intrusives of the Wilson Terrane, North Victoria Land, Antarctica. Eur. J. Mineral. 1990, 2, 103-124. [CrossRef]

20. Bomparola, R.M.; Ghezzo, C.; Belousova, E.; Griffin, W.L.; O'Reilly, S.Y. Resetting of the U-Pb Zircon System in CambroOrdovician Intrusives of the Deep Freeze Range, Northern Victoria Land, Antarctica. J. Petrol. 2007, 48, 327-364. [CrossRef]

21. Bradshaw, J.D.; Laird, M.G. The pre-Beacon Geology of Northern Victoria Land; Australian Academy of Science: Canberra, ACT, Australia, 1983. 
22. Weaver, S.D.; Bradshaw, J.D.; Laird, M.G. Geochemistry of Cambrian volcanics of the Bowers Supergroup and implications for the Early Palaeozoic tectonic evolution of northern Victoria Land, Antarctica. Earth Planet. Sci. Lett. 1984, 68, 128-140. [CrossRef]

23. Chen, H.; Wang, W.; Zhao, Y. Constraints on early Paleozoic magmatic processes and tectonic setting of Inexpressible Island, Northern Victoria Land, Antarctica. Adv. Polar Sci. 2019, 30, 52-69.

24. Peccerillo, A.; Taylor, S.R. Geochemistry of eocene calc-alkaline volcanic rocks from the Kastamonu area, Northern Turkey. Contrib. Mineral. Petrol. 1976, 58, 63-81. [CrossRef]

25. Biagini, R.; Cappelli, B.; Di Vincenzo, G. P-T Estimates of the Mt. Abbott Intrusives and Enclosed Metamorphic "Septa" at Terra Nova Bay (North Victoria Land, Antarctica); Vulcanismo Potassico: Ischia, Italy, 1990.

26. Lombardo, B.; Cappelli, B.; Carmignani, L.; Gosso, G.; Memmi, I.; Montrasio, A.; Palmeri, R.; Pannuti, F.; Pertusati, P.C.; Ricci, C.A.; et al. The metamorphic rocks of the Wilson Terrane between David and Mariner Glaciers, North Victoria Land, Antarctica. Mem. Soc. Geol. Ital. 1987, 33, 99-130.

27. Palmeri, R. P-T paths and migmatite formation: An example from Deep Freeze Range, northern Victoria Land, Antarctica. Lithos 1997, 42, 47-66. [CrossRef]

28. Kim, D.; Park, M.; Park, Y.; Qi, C.; Kim, H.; Lee, M.J.; Michibayashi, K. Upper mantle seismic anisotropy beneath the Northern Transantarctic Mountains inferred from peridotite xenoliths near Mt. Melbourne, northern Victoria Land, Antarctica. J. Struct. Geol. 2021, 143, 104237. [CrossRef]

29. GANOVEX. Geological Map of North Victoria Land, Antarctica, 1:500,000-Explanetory Notes; GANOVEX III; Geologisches Jahrbuch: Hannover, Germany, 1987; Volume 2.

30. Pertusati, P.C.; Musumeci, G.; Colombo, F.; Meccheri, M.; Baroni, C.; Capponi, G.; Carmignani, L.; Castelli, D.; Colombo, F.; Crispini, L.; et al. Mount Melbourne Quadrangle (Victoria Land), Geological 1:250,000 Map Series; GIGAMAP, Pertusati, P.C., Tessenshon, F.C., Eds.; Museo Nazionale Dell'Antartide: Siena, Italy, 2012.

31. Capponi, G.; Castelli, D.; Fioretti, A.M.; Oggiano, G. Geological Mapping and Field Relationships of the Eclogites from the Lanterman Range, Northern Victoria Land, Antarctica; Terra Antarctica Publications: Siena, Italy, 1997.

32. Middlemost, E.A.K. Naming materials in the magma/igneous rock system. Earth Sci. Rev. 1994, 37, 215-224. [CrossRef]

33. Paces, J.B.; Miller, J.D., Jr. Precise U-Pb ages of Duluth Complex and related mafic intrusions, northeastern Minnesota: Geochronological insights to physical, petrogenetic, paleomagnetic, and tectonomagmatic processes associated with the $1.1 \mathrm{Ga}$ Midcontinent Rift System. J. Geophys. Res. Sol. Earth 1993, 98, 13997-14013. [CrossRef]

34. Wiedenbeck, M.; Allé, P.; Corfu, F.; Griffin, W.L.; Meier, M.; Oberli, F.; Quadt, A.V.; Roddick, J.C.; Spiegel, W. Three natural zircon standards for U-Th-Pb, Lu-Hf, trace element and REE analyses. Geostand. Newsl. 1995, 19, 1-23. [CrossRef]

35. Ireland, T.R.; Williams, I.S. Considerations in Zircon Geochronology by SIMS; Reviews in Mineralogy and Geochemistry; Mineralogical Society of America: Chantilly, VA, USA, 2003; Volume 53.

36. Ludwig, K.R. User's Manual for SQUID 2; Berkeley Geochronology Center Special Publication: Berkeley, CA, USA, 2009.

37. Ludwig, K.R. User's Manual for Isoplot 3.6: A Geochronological Toolkit for Microsoft Excel; Berkeley Geochronology Center Special Publication: Berkeley, CA, USA, 2008.

38. Kuno, H. Lateral variation of basalt magma type across continental margins and Island Arcs. Bull. Volcanol. 1966, 29, 195-222. [CrossRef]

39. Irvine, T.N.; Baragar, W.R.A. A Guide to the Chemical Classification of the Common Volcanic Rocks. Can. J. Earth Sci. 1971, 8, 523-548. [CrossRef]

40. MacDonald, G.A.; Katsura, T. Chemical Composition of Hawaiian Lavas. J. Petrol. 1964, 5, 82-133. [CrossRef]

41. MacDonald, G.A. Composition and Origin of Hawaiian Lavas. In Studies in Volcanology; Coats, R.R., Hay, R.L., Anderson, C.A., Eds.; Geological Society of America: Boulder, CO, USA, 1968; Volume 116.

42. Wood, D.A. The application of a Th-Hf-Ta diagram to problems of tectonomagmatic classification and to establishing the nature of crustal contamination of basaltic lavas of the British Tertiary Volcanic Province. Earth Planet. Sci. Lett. 1980, 50, 11-30. [CrossRef]

43. Pearce, J. Sources and settings of granitic rocks. Int. Union Geol. Sci. 1996, 19, 120-125. [CrossRef]

44. Sun, S.S.; McDonough, W.F. Chemical and isotopic systematics of oceanic basalts: Implications for mantle composition and processes. Geol. Soc. Lond. Spec. Publ. 1989, 42, 313. [CrossRef]

45. Plank, T. The Chemical Composition of Subducting Sediments; Elsevier-Pergamon: Oxford, UK, 2014.

46. Rudnick, R.L.; Gao, S. Composition of the Continental Crust; Elsevier-Pergamon: Oxford, UK, 2014.

47. Wasserburg, G.J.; Jacobsen, S.B.; DePaolo, D.J.; McCulloch, M.T.; Wen, T. Precise determination of Sm/Nd ratios, Sm and Nd isotopic abundances in standard solutions. Geochim. Cosmochim. Acta 1981, 45, 2311-2323. [CrossRef]

48. DePaolo, D.J. Neodymium Isotope Geochemistry; Springer: Berlin/Heidelberg, Germany, 1988.

49. Faure, G. Origin of Igneous Rocks: The Isotopic Evidence; Springer: Berlin/Heidelberg, Germany, 2001.

50. Steiger, R.H.; Jäger, E. Subcommission on geochronology: Convention on the use of decay constants in geo- and cosmochronology. Earth Planet Sci. Lett. 1977, 36, 359-362. [CrossRef]

51. Begemann, F.; Ludwig, K.R.; Lugmair, G.W.; Min, K.; Nyquist, L.E.; Patchett, P.J.; Renne, P.R.; Shih, C.Y.; Villa, I.M.; Walker, R.J. Call for an improved set of decay constants for geochronological use. Geochim. Cosmochim. Acta 2001, 65, 111-121. [CrossRef]

52. Elliott, T.; Plank, T.; Zindler, A.; White, W.; Bourdon, B. Element transport from slab to volcanic front at the Mariana arc. J. Geophys. Res. Sol. Earth 1997, 102, 14991-15019. [CrossRef] 
53. Hawkesworth, C.J.; Turner, S.P.; McDermott, F.; Peate, D.W.; van Calsteren, P. U-Th Isotopes in Arc Magmas: Implications for Element Transfer from the Subducted Crust. Science 1997, 276, 551. [CrossRef] [PubMed]

54. Spandler, C.; Pirard, C. Element recycling from subducting slabs to arc crust: A review. Lithos 2013, 170, 208-223. [CrossRef]

55. Zheng, Y.-F. Subduction zone geochemistry. Geosci. Front. 2019, 10, 1223-1254. [CrossRef]

56. Kelemen, P.B.; Hanghøj, K.; Greene, A.R. One View of the Geochemistry of Subduction-Related Magmatic Arc, with an Emphasis on Primitive Andesite and Lower Crust; Elsevier-Pergamon: Oxford, UK, 2014.

57. Johnson, M.C.; Plank, T. Dehydration and melting experiments constrain the fate of subducted sediments. Geochem. Geophys. Geosystems 2000, 1. [CrossRef]

58. McCulloch, M.T.; Jaques, A.L.; Nelson, D.R.; Lewis, J.D. Nd and Sr isotopes in kimberlites and lamproites from Western Australia: An enriched mantle origin. Nature 1983, 302, 400-403. [CrossRef]

59. Fraser, K.J.; Hawkesworth, C.J.; Erlank, A.J.; Mitchell, R.H.; Scott-Smith, B.H. Sr, Nd and Pb isotope and minor element geochemistry of lamproites and kimberlites. Earth Planet. Sci. Lett. 1985, 76, 57-70. [CrossRef]

60. Conticelli, S.; Peccerillo, A. Petrology and geochemistry of potassic and ultrapotassic volcanism in central Italy: Petrogenesis and inferences on the evolution of the mantle sources. Lithos 1992, 28, 221-240. [CrossRef]

61. Zhang, H.F. Temporal and spatial distribution of Mesozoic mafic magmatism in the North China Craton and implications for secular lithospheric evolution. Geol. Soc. Lond. Spec. Publ. 2007, 280, 35. [CrossRef]

62. Pe-Piper, G.; Zhang, Y.; Piper, D.J.W.; Prelević, D. Relationship of Mediterranean type lamproites to large shoshonite volcanoes, Miocene of Lesbos, NE Aegean Sea. Lithos 2014, 184-187, 281-299. [CrossRef]

63. Yi, S.-B.; Oh, C.W.; Lee, S.-Y.; Choi, S.-G.; Kim, T.; Yi, K. Triassic mafic and intermediate magmatism associated with continental collision between the North and South China Cratons in the Korean Peninsula. Lithos 2016, 246, 149-164. [CrossRef]

64. Kay, S.M.; Abbruzzi, J.M. Magmatic evidence for Neogene lithospheric evolution of the central Andean "flat-slab" between $30^{\circ} \mathrm{S}$ and $32^{\circ} \mathrm{S}$. Tectonophysics 1996, 259, 15-28. [CrossRef]

65. Chapman, J.B.; Ducea, M.N.; Kapp, P.; Gehrels, G.E.; DeCelles, P.G. Spatial and temporal radiogenic isotopic trends of magmatism in Cordilleran orogens. Gondwana Res. 2017, 48, 189-204. [CrossRef]

66. Wodzicki, A.; Robert Jr, R. Geology of the Bowers Supergroup, Central Bowers Mountains, Northern Victoria Land. Geol. Investig. North. Vic. Land 1986, 39-68.

67. Borg, S.G.; Stump, E.; Chappell, B.W.; McCulloch, M.T.; Wyborn, D.; Armstrong, R.L.; Holloway, J.R. Granitoids of northern Victoria Land, Antarctica; implications of chemical and isotopic variations to regional crustal structure and tectonics. Am. J. Sci. 1987, 287, 127-169. [CrossRef]

68. Gibson, G.M.; Wright, T.O. Importance of thrust faulting in the tectonic development of northern Victoria Land, Antarctica. Nature 1985, 315, 480-483. [CrossRef]

69. Wright, T.O.; Ross, R.J., Jr.; Repetski, J.E. Newly discovered youngest Cambrian or oldest Ordovician fossils from the Robertson Bay terrane (formerly Precambrian), northern Victoria Land, Antarctica. Geology 1984, 12, 301-305. [CrossRef]

70. Kleinschmidt, G.; Tessensohn, F. Early Paleozoic Westward Directed Subduction at the Pacific Margin of Antartica. In Gondwana Six: Structure, Tectonics, and Geophysics; Wiley: Hoboken, NJ, USA, 1987; pp. 89-105.

71. Federico, L.; Crispini, L.; Capponi, G.; Bradshaw, J.D. The Cambrian Ross Orogeny in northern Victoria Land (Antarctica) and New Zealand: A synthesis. Gondwana Res. 2009, 15, 188-196. [CrossRef]

72. Federico, L.; Capponi, G.; Crispini, L. The Ross orogeny of the transantarctic mountains: A northern Victoria Land perspective. Int. J. Earth Sci. 2006, 95, 759-770. [CrossRef]

73. Rocchi, S.; Bracciali, L.; Di Vincenzo, G.; Gemelli, M.; Ghezzo, C. Arc accretion to the early Paleozoic Antarctic margin of Gondwana in Victoria Land. Gondwana Res. 2011, 19, 594-607. [CrossRef]

74. Di Vincenzo, G.; Horton, F.; Palmeri, R. Protracted ( 30Ma) eclogite-facies metamorphism in northern Victoria Land (Antarctica): Implications for the geodynamics of the Ross/Delamerian Orogen. Gondwana Res. 2016, 40, 91-106. [CrossRef]

75. Kim, T.; Kim, Y.; Cho, M.; Lee, J.I. P-T evolution and episodic zircon growth in barroisite eclogites of the Lanterman Range, northern Victoria Land, Antarctica. J. Metamorph. Geol. 2019, 37, 509-537. [CrossRef]

76. Kim, Y.; Kim, T.; Lee, J.I.; Kim, S.J. SHRIMP U-Pb ages of zircon from banded gneisses and a leucocratic dyke in the Wilson Terrane, northern Victoria Land, Antarctica. J. Geol. Soc. Korea 2017, 53, 489-507. [CrossRef]

77. Yi, S.-B.; Lee, M.J.; Lee, J.I.; Kim, H. Timing and metamorphic evolution of the Ross Orogeny in and around the Mountaineer Range, northern Victoria Land, Antarctica. Minerals 2020, 10, 908. [CrossRef]

78. Rocchi, S.; Di Vincenzo, G.; Dini, A.; Petrelli, M.; Vezzoni, S. Time-space focused intrusion of genetically unrelated arc magmas in the early Paleozoic Ross-Delamerian Orogen (Morozumi Range, Antarctica). Lithos 2015, 232, 84-99. [CrossRef]

79. Hagen-Peter, G.; Cottle, J.M.; Smit, M.; Cooper, A.F. Coupled garnet Lu-Hf and monazite U-Pb geochronology constrain early convergent margin dynamics in the Ross orogen, Antarctica. J. Metamorph. Geol. 2016, 34, 293-319. [CrossRef] 